\title{
Strategi Pengembangan Usaha Wisata Homestay Berbasis Komunitas di Kabupaten Raja Ampat, Provinsi Papua Barat
}

\section{The Development Strategy of Community-based Homestay Tourism Business in Raja Ampat Regency, West Papua Province}

\author{
Selna Adesetiani ${ }^{1, *}$, Lala M Kolopaking, Eriyatno
}

\begin{abstract}
${ }^{1}$ Program Studi Magister Pengembangan Masyarakat, Sekolah Pascasarjana IPB University, Bogor 16680, Indonesia
${ }^{*}$ E-mail korespondensi: selna des@apps.ipb.ac.id
\end{abstract}

Received: July 9, 2021 | Revised: November 11, 2021 | Accepted: November 23, 2021 | Online Publication: December 23, 2021

\section{ABSTRACT}

Raja Ampat is one of the regencies in Papua that has accelerated the development of tourism activities due to its biodiversity. The tourism potential of Raja Ampat impacts the transformation of social change from fishing tribes to sustainable ecotourism management communities. This study aims to analyze: 1) potentials, constraints, and needs for developing a community-based Homestay business of the indigenous people of Raja Ampat; 2) outsiders' intervention as well as financial access; 3) and the direction of community business development for homestay owners in Kampung Yenbuba and Kampung Arborek, Raja Ampat. The approach used in this study is a qualitative approach with a constructivism paradigm. The data collection techniques were done by applying the methods of observations, interviews, documentation, focus group discussions, and secondary data collections. The result showed that by managing a Homestay business in Raja Ampat, there was a significant increase in terms of the economy compared to when people worked as fishermen. The intervention from various parties such as the government, Non-Governmental Organizations, and the private sectors are very influential in implementing community-based tourism business development. Thus, there is a need for development directions in gaining access to various available resources and the participation of external parties to increase human resource capacity, access to finance, connectivity, and digitalization.

Keywords: community development, finance, homestay, intervention

\section{ABSTRAK}

Raja Ampat merupakan salah satu kabupaten yang berada di Provinsi Papua yang memiliki percepatan pengembangan kegiatan wisata berkat keragaman hayati yang dimilikinya. Potensi wisata Raja Ampat berdampak pada transformasi perubahan sosial masyarakat yang sebelumnya merupakan masyarakat nelayan menjadi masyarakat pengelola ekowisata berkelanjutan. Penelitian ini bertujuan untuk menganalisis: 1) potensi, kendala, dan kebutuhan pengembangan usaha homestay berbasis komunitas masyarakat asli Raja Ampat; 2) intervensi pihak luar serta akses pembiayaan; 3) dan arah pengembangan usaha komunitas pemilik Homestay Kampung Yenbuba dan Kampung Arborek, Raja Ampat. Pendekatan yang digunakan dalam penelitian ini adalah pendekatan kualitatif dengan paradigma konstruktivisme. Teknik pengumpulan data dilakukan dengan metode observasi, wawancara, dokumentasi, focus group discussion, dan pengumpulan data sekunder. Hasil penelitian menunjukkan bahwa dengan mengelola usaha homestay di Raja Ampat, terjadi peningkatan perekonomian yang signifikan dibandingkan saat mereka berprofesi sebagai nelayan. Adanya intervensi dari berbagai pihak seperti pemerintah, Lembaga Swadaya Masyarakat, dan swasta, sangat berpengaruh dalam mengimplementasikan pengembangan usaha pariwisata berbasis komunitas. Dengan demikian perlunya arah pengembangan dalam mendapatkan akses terhadap berbagai sumberdaya yang dimiliki serta partisipasi pihak luar dalam peningkatan kapastias SDM, akses pembiayaan, konektivitas, dan digitalisasi.

Kata kunci: pengembangan komunitas, pembiayaan, homestay, intervensi

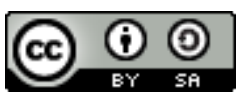




\section{PENDAHULUAN}

Pariwisata merupakan salah satu sektor ekonomi yang paling menjanjikan dan mempunyai tingkat pertumbuhan paling pesat di dunia. Tertuang pada Nesparnas (2017) pariwisata sebagai salah satu penggerak utama (key driver) kemajuan sosio-ekonomi suatu negara melalui penerimaan devisa, penciptaan lapangan pekerjaan dan kesempatan berusaha, serta pembangunan infrastruktur. Berdasarkan data yang tertera pada World Travel and Tourism Council (2020)menyatakan sumbangan pariwisata terhadap produk domestik bruto (PDB) dunia mencapai 10.4 persen atau 9,2 triliun AS dollar pada tahun 2019.

Perkembangan pesat sektor pariwisata di seluruh dunia, menjadikan peluang setiap negara untuk mempromosikan keindahan wisata negaranya masing-masing. Indonesia menjadi salah satu negara yang telah mengalami pertumbuhan sektor pariwisata yang pesat di tengah kompetisi pariwisata dunia. Sektor pariwisata nasional berkontribusi dalam sumber pendapatan terbesar negara. Berdasarkan data Nesparnas (2017) nilai transaksi ekonomi yang diciptakan dengan adanya kegiatan pariwisata mencapai Rp. 634 triliun pada tahun 2017 dan mengalami peningkatan sebesar 8,40 persen dibanding tahun 2016. Tertuang pada Laporan Kinerja Kementerian Pariwisata tahun (2019) dampak kegiatan pariwisata terhadap Produk Domestik Bruto (PDB) memberikan kontribusi 5,25\% dari total PDB nasional pada tahun 2018, yaitu jumlah devisa meningkat dari Rp 175,71 triliun pada tahun 2015 menjadi Rp 229,50 triliun pada tahun 2018.

Raja Ampat merupakan salah satu tujuan wisata andalan di Indonesia yang disematkan sebagai last paradise on earth karena terletak di jantung pusat segitiga karang dunia. Berdasarkan informasi Pemerintah Kabupaten Raja Ampat (2018) pengembangan usaha ekowisata dan wilayah Raja Ampat telah diusulkan sebagai Lokasi Warisan Dunia (World Herritage Site) oleh Pemerintah Indonesia dan telah dipertimbangkan oleh UNESCO. Dalam Peraturan Menteri Pariwisata Republik Indonesia Nomor 29 (2015) menyatakan bahwa destinasi ekowisata dikembangkan atas dasar potensi daya tarik wisata secara sinergis dengan pengembangan fasilitas wisata, fasilitas umum, sarana prasarana serta pemberdayaan masyarakat dalam kesisteman yang utuh dan berkelanjutan.

Adapun potensi ekowisata yang sudah dikenal wisatawan domestik dan mancanegara diantaranya Telaga Bintang, Wayag, Teluk Kabui, Pasir Timbul, Pulau Kelelawar, Piaynemo yang biasanya ditawarkan dalam bentuk paket wisata (Tanati et al., 2020). Peningkatan pengunjung ekowisata di Raja Ampat karena daya tarik potensi yang dimiliki senantiasa berdampak pada perubahan, perkembangan, dan pergantian pada sistem sosial masyarakat di mana perubahan-perubahan ini dalam ilmu sosial dinamakan perubahan sosial budaya (Pongantung, 2018). Penelitian (Aini et al., 2019) menyatakan bahwa perubahan sosial yang terjadi di Raja Ampat yaitu adanya peralihan mata pencarian masyarakat di Raja Ampat dari nelayan menjadi pengelola ekowisata. Transformasi mata pencaharian masyarakat Raja Ampat berdampak pada pola perilaku dan kehidupan masyarakat seperti, perilaku menjaga ekosistem lautan, mempertahankan dan tidak menjual lahan kepada investor luar, serta pengelolaan lahan dan sumberdaya berbasis konservasi.

Hasil penelitian Ade Yunita (2019) mengenai strategi pengembangan pariwisata berdasarkan preferensi masyarakat asli Raja Ampat telah memberikan rekomendasi untuk pengembangan pariwisata dalam bidang ekonomi, ekologi, dan sosial. Dalam bidang ekonomi, pemerintah daerah telah memberikan dukungan dalam program gerakan ekonomi masyarakat di desa-desa dengan memberikan kemudahan akses dalam mempromosikan dan memasarkan produk kerajinan maupun kebudayaan masyarakat asli Papua di Kepulauan Raja Ampat. Bidang ekologi pemerintah telah membentuk kerjasama masyarakat dengan pemerintah daerah seperti adanya kebijakan pemerintah daerah yang mengatur dan menjadikan masyarakat sebagai pengawas langsung yang mengawasi dan mengontrol lingkungan laut dari kerusakan. Sedangkan di bidang sosial, pengembangan pariwisata perlu melibatkan partisipasi masyarakat setempat untuk ikut serta melaksanakan pembangunan pariwisata. Hal ini bertujuan untuk meminimalkan terjadinya konflik kepentingan antar berbagai pihak yang peduli terhadap kegiatan pariwisata di Kepulauan Raja Ampat.

Potensi keindahan sumberdaya alam dan mulai banyaknya wisatawan yang mengunjungi Raja Ampat menjadi peluang untuk meningkatkan ekonomi berbasis pengembangan masyarakat yang berkelanjutan. Pada tahun 2009 Dinas Pariwisata dan Kebudayaan Raja Ampat mengajak masyarakat untuk membentuk kelompok sadar wisata dengan diberikan bantuan berupa homestay yang dikelola bersama kelompok sebagai homestay percontohan. Definisi homestay dalam penelitian Ningrum et al., 
(2019) merupakan jenis akomodasi yang menggunakan rumah penduduk setempat sebagai tempat penginapan sementara untuk wisatawan dan umumnya homestay memberikan pelayanan kamar beserta makanan dan minuman. Dalam penelitian He et al., (2008) distribusi manfaat yang tidak proporsional di antara para pemangku kepentingan dapat mengarah pada kegagalan ekowisata dan konservasi. Intervensi pihak luar seperti pemberian modal, pemberian informasi dan pemberian akses terhadap masyarakat dalam pengelolaan ekowisata dapat meningkatkan manfaat ekowisata yang diterima oleh masyarakat lokal.

Berdasarkan UU No. 26 Tahun 2002 tentang pembentukan kabupaten, Kepulauan Raja Ampat dideklarasikan sebagai salah satu kabupaten yang berada di Provinsi Papua dan memiliki percepatan pengembangan kegiatan wisata berkat keragaman hayati yang dimilikinya KKP (2012). Dari data BPS Kabupaten Raja Ampat (2020) Kabupaten Raja Ampat dari tahun 2013 - 2019 terhitung total 112.573 turis mancanegara yang berwisata ke Raja Ampat dengan rata-rata 16.082 turis yang berkunjung setiap tahunnya. Peningkatan turis domestik pun tidak kalah banyaknya dengan turis mancanegara, walaupun biaya untuk dapat berwisata di Raja Ampat cukup mahal dan tidak ada perbedaan untuk biaya yang dikenakan untuk turis domestik maupun mancanegara. Sebanyak 94.766 turis domestik datang berkunjung ke wisata Raja Ampat dengan rata-rata 13.538 wisatawan dometik setiap tahunnya.

Percepatan pertumbuhan sektor pariwisata Raja Ampat tentunya dimanfaatkan dengan baik oleh masyarakat asli Raja Ampat dengan membangun homestay-homestay di lahan pribadi milik mereka dan sebagian besar pemilik homestay di Kabupaten Raja Ampat sudah tergabung dalam Asosiasi homestay Raja Ampat. Sebagai daerah konservasi, Kabupaten Raja Ampat memandang penting untuk mengelola kawasan konservasi berbasis masyarakat secara profesional dan berkelanjutan. Dalam Kenny et al., (2018), pengembangan komunitas adalah proses yang difokuskan pada interaksi sosial yang meningkatkan koneksi manusia untuk membangun kapasitas komunitas. Interaksi dan komunikasi yang disengaja antara individu mengarah pada pengembangan ikatan sosial yang lemah dan kuat didalam dan lintas bidang sosial. Ikatan sosial memungkinkan informasi untuk dibagikan, sumber daya diidentifikasi dan tindakan harus terorganisir.

Dalam aspek pengelolaan pariwisata tidak terlepas dari peran komunitas dan para pemangku kepentingan seperti pemerintah, LSM dan swasta. Pemangku kepentingan adalah pihak-pihak yang berperan dalam melakukan intervensi terhadap komunitas untuk mempengaruhi dan dapat dipengaruhi juga oleh keputusan maupun tindakan orang disekitarnya. Tertuang pada penelitian Reed et al. (2009) analisis stakeholder atau pemetaan pemangku kepentingan penting dilakukan untuk mendefinisikan aspek fenomena dinamika sosial dan alam yang dipengaruhi oleh keputusan atau tindakan baik dari pihak dalam maupun pihak luar, serta mengetahui relasi antar pihak dalam keterlibatan pengambilan keputusan.

Upaya untuk menemukan berbagai faktor dan unsur-unsur yang dapat mendorong pengembangan pembiayaan berbasis komunitas di kabupaten konservasi dengan melakukan identifikasi potensi dan masalah serta melakukan evaluasi dan perencanaan aksi program. Hasil dari identifikasi dan evaluasi program tersebut akan menjadi dasar dalam proses perumusan strategi pengembangan program wisata homestay berbasis komunitas di Raja Ampat. Untuk memperkuat rumusan strategi pengembangan pembiayaan, maka analisis dalam usaha-usaha yang dijalankan oleh lembaga ekonomi komunitas yang ada serta analisis regulasi terkait pengembangan komunitas homestay juga penting dilakukan.

Berdasarkan latar belakang di atas, penelitian ini hendak menjawab permasalahan utama berupa "Strategi apa yang dapat dikembangkan untuk menguatkan usaha wisata berbasis komunitas homestay Raja Ampat?" Secara khusus, penelitian ini ingin menjawab masalah-masalah sebagai berikut: 1) Seperti apa potensi, kendala, dan kebutuhan pengembangan usaha homestay berbasis komunitas masyarakat asli Raja Ampat ? 2) Apa saja intervensi pihak luar serta bagaimana akses pembiyaannya? 3) dan bagaimana arah pengembangan usaha komunitas pemilik homestay Kampung Yenbuba dan Kampung Arborek?

\section{METODE}

Penelitian ini menggunakan metode penelitian kualitatif yang didukung dengan data kuantitatif. Lokasi penelitian dilaksanakan penelitian ini dilakukan di dua kampung yaitu Kampung Yenbuba dan Kampung Arborek yang berada Distrik Meos Mansar dan merupakan bagian dari wilayah Selat Dampier Kabupaten Raja Ampat, Papua Barat. Pengumpulan data penelitian menggunakan paradigma 
konstruktivisme dengan Pendekatan penelitian kualitatif dilakukan melalui metode partisipatif menggunakan teknik Focus Group Discussion (FGD). Melalui paradigma dan pendekatan tersebut peneliti dapat mengembangkan makna-makna subjektif atas pengalaman dengan mengajukan pertanyaan-pertanyaan untuk mencari kompleksitas pandangan ketimbang mempersempit maknamakna menjadi kategori dan gagasan (Creswell, 2018). Metode penentuan informan secara purposive (sengaja) serta data yang digunakan dalam penelitian ini adalah data primer dan data sekunder. Data primer dikumpulkan melalui pengamatan, dan wawancara mendalam sejumlah informan dengan menggunakan panduan pertanyaan. Selain dengan kegiatan wawancara mendalam, data primer digali melalui diskusi kelompok, sedangkan data sekunder dikumpulkan dari dokumen-dokumen yang relevan dengan penelitian ini baik ditingkat kampung maupun kabupaten secara ringkas termuat pada Tabel 1 di bawah ini.

Tabel 1 Proses pengumpulan data strategi pengembangan homestay berbasis komunitas homestay Raja Ampat

\begin{tabular}{|c|c|c|c|c|}
\hline No & Aspek & $\begin{array}{l}\text { Jenis dan Sumber } \\
\text { Data }\end{array}$ & $\begin{array}{l}\text { Metode } \\
\text { Pengumpulan Data }\end{array}$ & $\begin{array}{l}\text { Metode Analisis } \\
\text { Data }\end{array}$ \\
\hline 1 & $\begin{array}{l}\text { Mengidentifikasi potensi } \\
\text { dan kondisi homestay di } \\
\text { Kabupaten Konservasi } \\
\text { Raja Ampat }\end{array}$ & $\begin{array}{l}\text { Data primer dan } \\
\text { data sekunder }\end{array}$ & $\begin{array}{l}\text { Wawancara dan } \\
\text { kunjungan ke } \\
\text { instansi }\end{array}$ & $\begin{array}{l}\text { analisis deskriptif } \\
\text { kualitatif }\end{array}$ \\
\hline 2 & $\begin{array}{l}\text { Profil Komunitas } \\
\text { homestay Raja Ampat }\end{array}$ & $\begin{array}{l}\text { Data primer dan } \\
\text { data sekunder }\end{array}$ & $\begin{array}{l}\text { Wawancara dengan } \\
\text { pemilik Homestay } \\
\text { Raja Ampat }\end{array}$ & $\begin{array}{l}\text { analisis deskriptif } \\
\text { kualitatif }\end{array}$ \\
\hline 3 & $\begin{array}{l}\text { Mengidentifikasi peran } \\
\text { pemangku kepentingan } \\
\text { dan klasifikasi usaha } \\
\text { Homestay di Kabupaten } \\
\text { Konservasi Raja Ampat }\end{array}$ & Data primer & $\begin{array}{l}\text { Wawancara } \\
\text { mendalam, FGD }\end{array}$ & $\begin{array}{l}\text { analisis } \\
\text { stakeholder } \\
\text { secara kualitatif }\end{array}$ \\
\hline
\end{tabular}

Penelitian ini dilakukan dengan pendekatan kualitatif di mana sumber data dalam penelitian ini adalah informan sebagai subjek yang menjelaskan mengenai kondisi di lingkungannya. Pada penelitian ini yang menjadi informan adalah Dinas Pariwisata dan Kebudayaan Kabupaten Raja Ampat, Dinas Koperasi dan UKM Kabupaten Raja Ampat, Pemerintah Kampung, Pengurus Asosiasi Homestay Raja Ampat dan komunitas pemilik homestay Raja Ampat yang berada di Kampung Yenbuba dan Kampung Arborek. Pemilihan informan menggunakan teknik purposive sampling, di mana penentuan informan direncanakan dan peneliti mengandalkan penilaiannya sendiri untuk memilih informan untuk berpartisipasi dalam penelitian sesuai dengan kebutuhan untuk menjawab tujuan penelitian.

Pengolahan Seluruh data dan informasi yang terkumpul dilakukan melalui analisis data kualitatif dengan tiga tahap yaitu reduksi data, penyajian data, dan verifikasi Milles dan Huberman 1992 dalam (Creswell, 2018). Reduksi data dimulai dari proses pemilihan, penyederhanaan data hasil wawancara mendalam, observasi, dan studi dokumen. Tujuan dari reduksi data adalah untuk mempertajam, menggolongkan, mengarahkan, dan membuang data yang tidak perlu. Kedua ialah penyajian data yang berupa menyusun segala informasi dan data yang diperoleh menjadi serangkaian kata-kata yang mudah dibaca ke dalam sebuah laporan. Penyajian data berupa narasi, diagram, dan matriks. Verifikasi adalah langkah terakhir yang merupakan penarikan kesimpulan dari hasil yang telah diolah pada tahap reduksi. 


\section{HASIL DAN PEMBAHASAN}

\section{Pemetaan Sosial Komunitas Homestay Raja Ampat}

Perkembangan homestay di Raja Ampat berawal dari datangnya seorang penyelam dari Belanda bernama Max Ammer di tahun 1993 yang datang ke Raja Ampat untuk melakukan perjalanan menggunakan kayak bersama dengan seorang pemandu wisata bernama Otto. Max Ammer yang kagum akan keindahan alam Raja Ampat mulai melakukan pendekatan dengan cara menetap sementara di Kampung Batanta. Setelah merasa diterima dengan penduduk kampung Batanta, Max Ammer mulai membangun usaha penyelaman Papua Diving dan akhirnya berkembang menjadi resort. Pada tahun 1998 sempat terjadi perselisihan antara Max Ammer dengan warga Batanta dan mengakibatkan aksi pembakaran resort Max Ammer. Di tahun 1999 Max Ammer membangun kembali resort yang diberi nama Kri Eco Resort - Papua Diving yang didirikan di Pulau Kri.

Pada tahun 2003, Bupati Papua menetapkan Raja Ampat sebagai kabupaten baru di mana pemerintah daerah Raja Ampat dapat menjalankan kewenangan maupun peran administrasinya secara otonom. Setelah resminya Raja Ampat menjadi kabupaten baru, terdapat beberapa peraturan baru yang ditetapkan untuk pembangunan wilayah Raja Ampat. Peraturan baru tersebut salah satunya adalah Perda No 27 tahun 2008 tentang Kawasan Konservasi Laut Daerah Kabupaten Raja Ampat. Penetapan wilayah konservasi meliputi wilayah laut Sayang-Wayag, Telut Mayalibit, Ayau-Asia, Kofiau-Boo, Misol Timur Selatan, dan Selat Dampier. Dalam penelitian ini Kampung Yenbuba dan Kampung Arborek masuk kedalam wilayah Selat Dampier, yang setelah penetapan perda KKLD masuk kedalam dua subzona yaitu: 1) subzona ketahanan pangan dan pariwisata; dan 2) subzona sasi menurut Febyarandika et al., (2016) diartikan sebagai sanksi yaitu salah satu adat istiadat yang telah ada sejak ribuan tahun silam. Dalam tradisi Sasi, masyarakat sepakat untuk tidak menangkap biota yang di sasi selama setahun. Pelarangan ini bertujuan untuk memberikan kesempatan kepada biota tersebut untuk berkembang dan agar tidak punah dan pemanfaatan tradisional masyarakat. Sehingga masyarakat kampung tersebut diperbolehkan melakukan kegiatan pariwisata dan pemanfaatan tradisional masyarakat. Dalam proses penetapan perda Kawasan Konservasi Laut Daerah Kabupaten Raja Ampat tersebut, diawali dengan lokakarya pengembangan strategi konservasi Raja Ampat di mana masyarakat diberi kesempatan untuk berpartisipasi aktif dalam perumusan dan implementasi strategi pembangunan berkelanjutan, kemudian rencana tersebut menghasilkan transformasi masyarakat dalam menjaga sumber daya alam untuk dimanfaatkan sebagai daya tarik wisata.

Dinas Pariwisata dan Kebudayaan Raja Ampat di tahun 2011 membentuk kelompok sadar wisata dan membangun satu homestay yang dikelola oleh kelompok sadar wisata di Kampung Arborek. Homestay percontohan dibangun di lahan milik Bapak Nomensen Mambraku yang juga merupakan salah satu aparatur pemerintah kampung. Kelompok sadar wisata ini hanya bertahan selama satu tahun karena merasa kurangnya transparasi dana pemasukan dan pengeluaran. Selain itu melihat semakin meningkatnya wisatawan yang berkunjung ke Arborek, sehingga mendorong beberapa anggota kelompok sadar wisata memilih untuk membangun homestay sendiri.

Tertuang dalam Seventythree Ltd (2013) lembaga seventythree mengunjungi Raja Ampat khususnya kawasan Selat Dampier untuk menjalankan proyek memperkuat kapasitas pengusaha lokal yang memiliki dan mengoperasikan homestay di Kepulauan Raja Ampat. Seventythree membentuk kelompok yang bernanma Asosiasi Homestay Raja Ampat dan melakukan pelatihan model bisnis. Selain memberikan pelatihan-pelatihan mengenai bisnis wisata berkelanjutan, seventythree juga menyediakan website stayrajaampat.com untuk mempromosikan homestay masyarakat lokal. Dari sinilah awal mula berkembangnya homestay Raja Ampat dan terjadi peningkatan jumlah wisatawan baik mancanegara maupun domestik ke Raja Ampat. Berikut data wisatawan mancanegara dan wisatawan domestik yang datang berkunjung dari tahun 2013 - 2017 menurut data BPS Kab Raja Ampat 


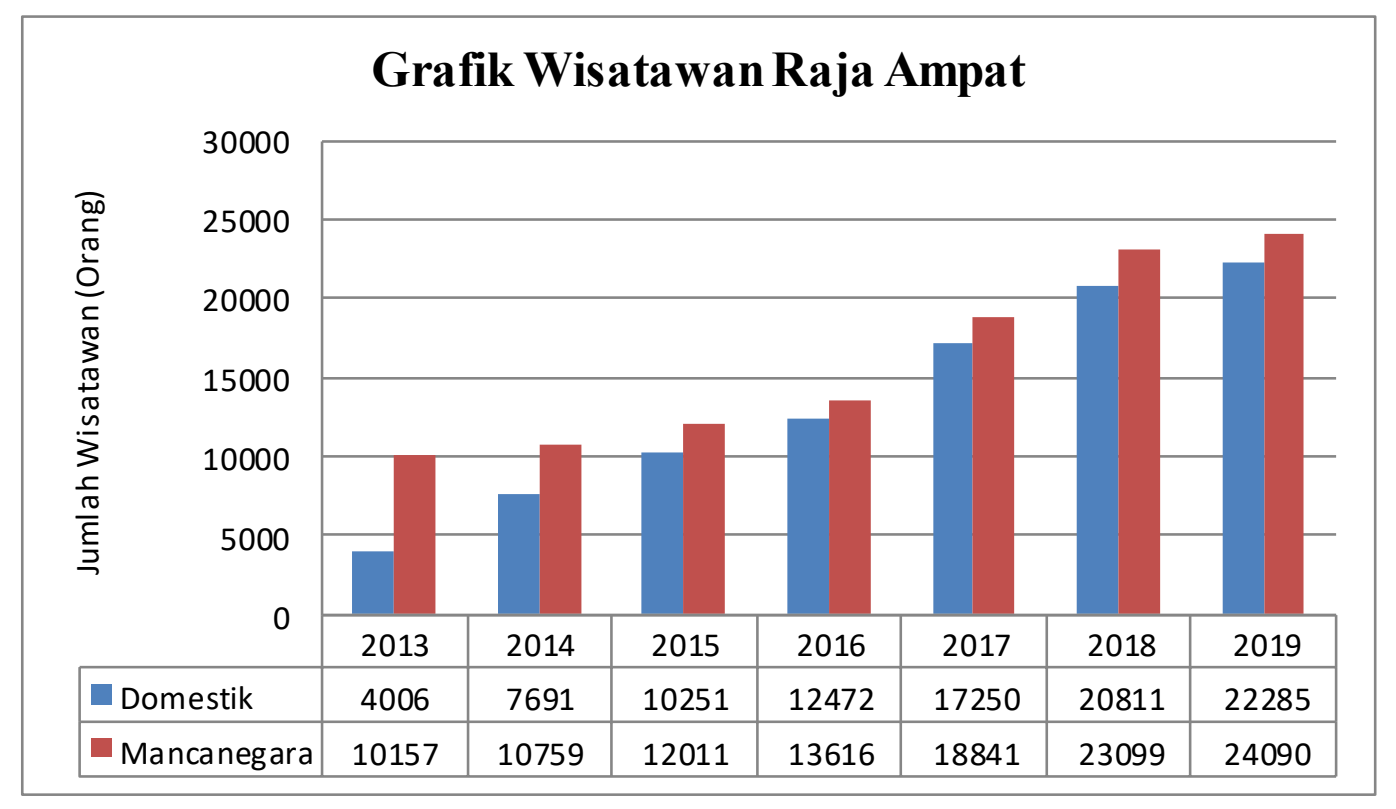

Gambar 1 Jumlah Wisatawan Domestik dan Mancanegara ke Raja Ampat tahun 2013-2019

Sumber: Data BPS Kabupaten Raja Ampat, 2021

Meningkatnya jumlah wisatawan yang berkunjung ke Raja Ampat setiap tahunnya, menjadi peluang masyarakat lokal dalam mengelola ekowisata berkelanjutan. Nilai indeks desa membangun (IDM) Distrik Meos Mansar Kab Raja Ampat pada tahun 2019 nila rata-rata dari 9 kampung yang ada di Distrik Meos Mansar adalah 0.5417 yang berarti kecamatan ini terkategori tertinggal (Kemendesa 2020). Nilai IDM ini terkait dengan aspek sosial, ekonomi dan ekologi. Dari dua kampung penelitian, Kampung Yenbuba memiliki nilai IDM 0.605 pada tahun 2019 dan masuk dalam kategori berkembang sedangkan Kampung Arborek masuk dalam kategori tertinggal pada tahun 2018 dan belum ada nilai IDM terbaru di tahun 2019. Dari hasil wawancara dengan pemlik homestay yang sebelumnya berprofesi sebagai nelayan ada peningkatan pendapatan yang signifikan setelah beralih profesi menjadi pengelola homestay. Pendapatan yang biasanya hanya Rp. 3.000.000 - Rp. 5.000.000 saat masih menjadi nelayan, saat ini mereka dapat menghasilkan minimal 15 juta dengan mengelola homestay.

Dalam data Dinas Koperasi dan UKM Kabupaten Raja Ampat tercatat pada tahun 2020 sudah terdapat sekitar 112 bangunan homestay yang dimilki oleh masyarakat asli yang sersebar diseluruh pulau di Raja Ampat dengan sekitar 80 persennya berada di awasan Selat Dampier. Pemerintah daerah Raja Ampat menetapkan Selat Dampier sebagai lokasi utama pariwisata bahari di Kabupaten Raja Ampat. Enam kampung di Selat Dampier, yaitu kampung Sawinggrai, Arborek, Sawandarek, Yenbuba, Yenwaupnor dan Arefi, telah ditetapkan sebagai kampung Wisata. Penetapan Selat Dampier sebagai lokasi utama pariwisata di Raja Ampat dikarenakan potensi bawah laut nya yang luar biasa dan lokasi berada dekat dengan Ibu Kota Kabupaten Raja Ampat. KKPD Selat Dampier secara geografis terdiri dari 3 bagian yaitu pesisir Pulau Gam dan Mansuar, pesisir Pulau Batanta dan Pesisir Pulau Salawati, dengan luas $336.000 \mathrm{Ha}$.

Phillips \& Pittman (2009) memaknai komunitas dengan merujuk pada tempat tinggal (communities of place) dan kepentingan (communities of interest). Dari pemahaman tersebut pengembangan masyarakat dapat diartikan sebagai proses tumbuh dan berkembangnya masyarakat kearah perubahan yang positif bersama-sama. Komunitas menurut Ife \& Tesoriero (2008) merupakan warga setempat yang dapat dibedakan dari masyarakat lebih luas (society) melalui kepentingan bersama (a community of interest) atau tingkat interaksi yang tinggi. Para anggota komunitas memiliki kebutuhan yang bersama (common needs). Jika tidak memilki kebutuhan bersama, itu bukan suatu komunitas. Komunitas dalam penelitian ini merupakan komunitas pemilik Homestay yang merupakan masyarakat asli papua yang sebagian besar merupakan suku biak yang memiliki dan melakukan aktivitas pengelolaan usaha homestay di kawasan wisata Raja Ampat. Komunitas pemilik homestay Raja 
Ampat didefinisikan sebagai masyarakat asli papua yang memiliki kepentingan bersama yaitu dalam mengelola homestay dan juga memiliki interaksi dan tujuan bersama untuk meningkatkan perekonomian dan mengelola wisata berkelanjutan di Raja Ampat. Penelitian ini mengambil komunitas homestay Raja Ampat yang berada di Kampung Yenbuba dan Kampung Arborek.

Pemilihan kedua kampung lokasi penelitian karena memiliki karakteristik yang sama yaitu merupakan destinasi atau tempat singgah yang paling sering dikunjungi oleh wisatawan karena lokasi yang strategis dan dekan dengan spot-spot wisata baik wisata diving maupun wisata landscape. Selain itu, yang menjadi fokus penelitian dikarenakan komunitas pengusaha Kampung Arborek sudah pernah mendapatakan pembiayaan dari perbankan berupa KUR sedangkan Kampung Yenbuba masih menggunakan pembiayaan pribadi, tetapi dari segi skala usaha homestay tidak ada perbedaan yang signifikan antara kedua kampung. Sebaran homestay di kedua kampung dapat dilihat pada Gambar 2 dan Gambar 3.

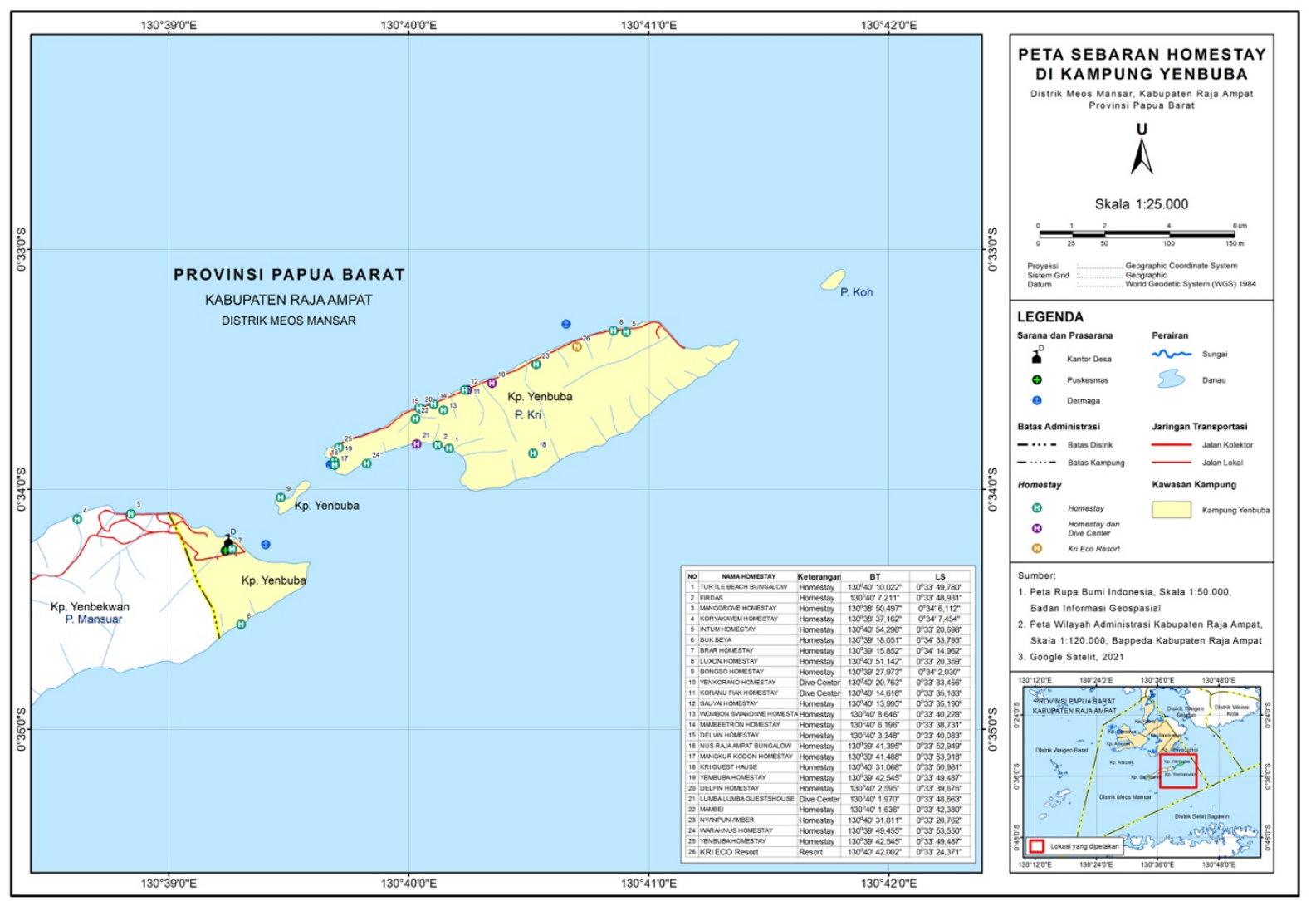

Gambar 2. Peta Sebaran Homestay Kampung Yenbuba Pulau Kri, Raja Ampat tahun 2021

Sumber: Data Asosiasi Homestay Raja Ampat (Diolah), 2021

Kampung Yenbuba memiliki 25 homestay yang dikelola oleh masyarakat asli dan satu resort milik investor dari Belanda bernama Max Ammer. Masyarakat Kampung Yenbuba membangun homestay mereka di pulau kri yang merupakan pulau sendiri yang tidak dihuni oleh penduduk kampung. Homestay di pulau Kri adalah homestay yang paling sering dikunjungi wisatawan mancanegara dikarenakan dekat dengan kampung Arborek yang merupakan tempat transit wisatawan dan juga dekat dengan spot-spot diving.

Kampung Arborek memiliki 13 homestay yang dikelola oleh masyarakat asli dan berlokasi di pesisir pulau Arborek. Pulau Arborek ditetapkan sebagai kampung wisata dan tempat transit para turis yang sedang berwisata ke Raja Ampat. Pulau Arborek merupakan destinasi favorit wisatawan karena terdapat spot diving bersama manta dan spot-spot diving lainnya yang menjadi daya tarik dari Raja Ampat terdapat di sekitar Pulau Arborek, sebaran homestay di Pulau Arborek dapat dilihat pada Gambar 3. 


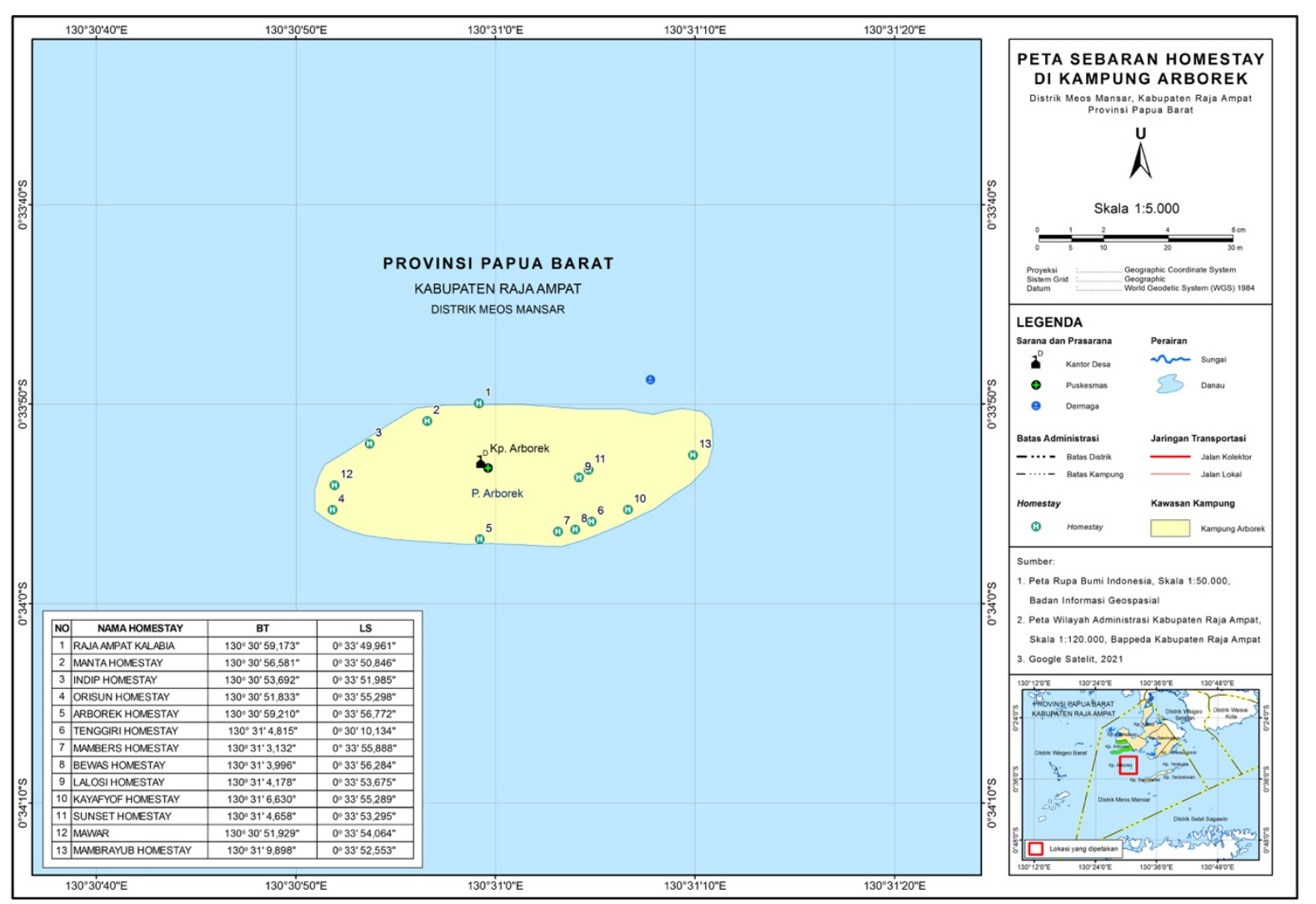

Gambar 3 Peta Sebaran Homestay Kampung Arborek, Raja Ampat, 2021

Sumber: Data Asosiasi Homestay Raja Ampat (Diolah), 2021

\section{Modal Komunitas Pemilik Homestay Raja Ampat}

Komunitas pelaku usaha homestay Raja Ampat pada penelitian ini diidentifikasi berdasarkan letak geografis yaitu Selat Dampier dan lebih spesifiknya lagi berada di Kampung Yenbuba dan Kampung Arborek. Ciri-ciri komunitas pelaku usaha homestay Raja Ampat dalam penelitian ini diidentifikasi melalui modal komunitas (Oktadiyani et al., 2016) yang mencakup sumberdaya yang dapat dipandang sebagai investasi untuk mendapatkan sumberdaya baru. Dalam Green (2010) membagi enam aset atau potensi komunitas yang melekat pada setiap masyarakat dan diasumsikan dapat terkait dengan upaya pengembangan masyarakat. Adapun keenam modal tersebut adalah modal fisik, modal finansial, modal lingkungan, modal teknologi, modal manusia dan modal sosial. Pentingnya mengetahui modal sosial dalam pengembangan ekowisata karena keberhasilan pengembangan ekowisata di suatu kawasan memerlukan adanya keseimbangan antara aspek lingkungan, ekonomi, dan sosial budaya (Goeldner \& Ritchie, 2005).

\section{Modal Fisik}

Modal fisik terdiri dari dua kelompok utama yaitu, bangunan dan infrastruktur. Bangunan yang di maksud berupa rumah, gedung, pertokoan, perkantoran dan lain-lain, sedangkan infrastruktur berupa jalan, jembatan, sarana air bersih, jaringan telepon dan lain-lain. Modal sumberdaya fisik komunitas homestay Raja Ampat dalam penelitian ini dilihat dari: ketersediaan fasilitas umum, kondisi fasilitas umum, ketersediaan moda transportasi, serta akses informasi dan komunikasi. Dari hasil observasi dan wawancara sumberdaya fisik yang ada di komunitas cukup baik untuk mendukung kegiatan pariwisata di kedua kampung walaupun masih banyak keterbatasan dan kendala dalam mengakses sumberdaya fisik tersebut. 
Tabel 2 Modal fisik komunitas homestay Raja Ampat (Kampung Yenbuba dan Kampung Arborek), 2020

\begin{tabular}{|c|c|}
\hline Indikator & Keterangan \\
\hline $\begin{array}{l}\text { Fasilitas homestay dan } \\
\text { kondisi homestay }\end{array}$ & $\begin{array}{l}\text { Fasilitas yang diberikan homestay beragam, ada yang memilki kamar } \\
\text { mandi dalam dan kamar mandi luar, ruang gazebo untuk berkumpul } \\
\text { dan makan, kondisi homestay sebagian besar masih sederhana } \\
\text { dibangun dengan papan kayu, dinding daun bobo dan atap daun sagu. }\end{array}$ \\
\hline $\begin{array}{l}\text { Ketersediaan fasilitas } \\
\text { umum }\end{array}$ & $\begin{array}{l}\text { Failitas umum yang tersedia cukup lengkap, antara lain fasilitas } \\
\text { kesehatan, sekolah, tempat peribadatan }\end{array}$ \\
\hline Kondisi fasilitas umum & Kondisi fasilitas umum cukup baik dan dapat digunakan \\
\hline $\begin{array}{l}\text { Ketersediaan moda } \\
\text { transportasi }\end{array}$ & $\begin{array}{l}\text { Tidak terdapat moda transportasi umum, hanya dapat menggunakan } \\
\text { kendaraan pribadi }\end{array}$ \\
\hline \multirow{2}{*}{$\begin{array}{l}\text { Akses informasi dan } \\
\text { komunikasi }\end{array}$} & Sinyal jaringan komunikasi cukup baik \\
\hline & $\begin{array}{l}\text { Tapi masih terbatas, kesediaan listrik hanya dari pukul } 6 \text { sore hingga } \\
\text { pukul } 12 \text { malam }\end{array}$ \\
\hline
\end{tabular}

\section{Modal Finansial}

Modal finansial adalah dukungan finansial yang dimiliki suatu komunitas yang dapat digunakan untuk membiayai proses pembangunan yang diadakan dalam komunitas tersebut. Modal keuangan komunitas homestay dalam penelitian ini dilihat dari: keberadaan kelembagaan keuangan, aksesibilitas terhadap lembaga keuangan, literasi keuangan, unit usaha wisata yang dikelola, keberadaan fasilitas pendukung dan pusat pelayanan wisata, dan akses distribusi/logistik. Berdasarkan hasil observasi dan wawancara, modal keuangan komunitas pemilik homestay Raja Ampat tidak cukup untuk mendukung kegiatan perekonomian komunitas, selain itu keberadaan kelembagaan keuangan pun belum ada di kedua kampung dan jarak cukup jauh untuk mengakses lembaga keuangan. Tabel 3 menyajikan informasi modal keuangan komunitas homestay Raja Ampat dari kedua kampung.

Tabel 3 Modal keuangan komunitas homestay Raja Ampat (Kampung Yenbuba dan Kampung Arborek), 2020

\begin{tabular}{ll}
\hline Indikator & Keterangan \\
\hline $\begin{array}{l}\text { Keberadaan kelembagaan } \\
\text { keuangan }\end{array}$ & $\begin{array}{l}\text { Belum ada lembaga keuangan di kedua kampung. Lembaga } \\
\text { keuangan seperti koperasi, bank, dan lainnya hanya tersedia di } \\
\text { ibukota kabupaten }\end{array}$ \\
$\begin{array}{l}\text { Aksesibilitas terhadap lembaga } \\
\text { keuangan }\end{array}$ & $\begin{array}{l}\text { Cukup sulit diakses karena jarak yang harus ditempuh } \\
\text { menggunakan speedboat ke Ibukota Kabupaten dan memakan } \\
\text { banyak biaya. }\end{array}$ \\
Literasi Keuangan & $\begin{array}{l}\text { Rendah, anggota komunitas tidak memiliki pengetahuan yang } \\
\text { cukup mengenai pinjaman di lembaga keuangan dan takut untuk } \\
\text { mengakses keuangan dari pihak luar. }\end{array}$ \\
$\begin{array}{l}\text { Hanya sebagian kecil yang dapat memenuhi kebutuhan wisatawan } \\
\text { seperti fasilitas penginapan, tourguide, transportasi, paket }\end{array}$ \\
menyelam, penyewaan alat selam dan produksi kerajinan tangan \\
$\begin{array}{l}\text { Keberadaan fasilitas } \\
\text { pendukung dan pusat } \\
\text { pelayanan wisata }\end{array}$ & $\begin{array}{l}\text { Terdapat dua jenis pusat pelayanan wisata. Kantor PERJAMPAT } \\
\text { dan BLUD yang bertugas mengelola data pengunjung masuk dan } \\
\text { bertanggung jawab saat terjadi kecelakaan pada wisatawan. }\end{array}$ \\
Akses distribusi/logistik & $\begin{array}{l}\text { Di kedua kampung tidak terdapat jasa pos maupun jasa logistik } \\
\text { swasta, logistik hanya bisa didapatkan di Ibukota Raja Ampat } \\
\text { yaitu Waisai yang jaraknya cukup jauh dari keduakampung. }\end{array}$ \\
\hline
\end{tabular}




\section{Modal Teknologi}

Modal teknologi merupakan ketersediaan teknologi tepat guna yang bermanfaat untuk masyarakat, dan bukan sekadar teknologi digital yang canggih, akan tetapi belum tentu bermanfaat bagi masyarakat tersebut. Modal teknologi komunitas homestay Raja Ampat dalam penelitian ini dilihat dari: ketersediaan teknologi dan kondisi teknologi tersebut. Hasil penilaian terhadap modal teknologi disajikan pada Tabel 4. Beradasarkan Tabel 4 dapat diketahui bahwa modal teknologi komunitas masih sangat rendah dan sederhana serta belum ada teknologi yang diciptakan untuk membantu menunjang komunitas.

Tabel 4 Modal Teknologi komunitas homestay Raja Ampat (Kampung Yenbuba dan Kampung Arborek), 2020

\begin{tabular}{ll}
\hline Indikator & Keterangan \\
\hline Ketersediaan Teknologi & $\begin{array}{l}\text { Ketersediaan Teknologi masih rendah, hanya penggunaan telepon } \\
\text { genggam dan sinyal internet juga website yang dikelola oleh asosiasi }\end{array}$ \\
Kondisi Teknologi & $\begin{array}{l}\text { Kondisi teknologi masih minim dan perlu adanya teknologi baru yang } \\
\text { bisa disesuaikan dengan kebutuhan }\end{array}$ \\
\hline
\end{tabular}

\section{Modal SDM}

Modal manusia merupakan sumber daya manusia yang berkualitas sehingga dapat menguasai teknologi yang bermanfaat bagi masyarakat, baik itu teknologi yang sederhana maupun yang canggih. Sumber daya manusia menjadi modal komunitas yang penting dalam menunjang kehidupan komunitas. Modal SDM dalam penelitian ini dibagi dalam beberapa indikator seperti tingkat pendidikan dan akses masyarakat terhadap pendidikan, keterampilan, serta tingkat kesehatan dan usia mayoritas masyarakat. Mayoritas pemilik homestay berada pada usia produktif dengan tingkat pendidikan terkategori rendah yaitu sebagian besar merupakan lulusan SD atau bahkan tidak tamat SD. Selain tingkat pendidikan rendah untuk akses terhadap fasilitas pendidikan dan tenaga pendidik pun belum memadai, fasilitas pendidikan hanya sampai tingkatan SD dengan tenaga pendidik yang terbatas dan jarak yang cukup jauh untuk mencapai fasilitas tingkat SMP dan seterusnya. Rendahnya tingkat kesadaran akan pentingnya mengenyam pendidikan minimal wajib belajar sembilan tahun juga menjadi alasan banyaknya masyarakat yang tidak melanjutkan pendidikan dan lebih memilih bekerja menjadi nelayan atau pengelola usaha wisata di kampung sendiri.

Aspek keterampilan yang dimiliki oleh komunitas pemilik homestay adalah mengelola homestay serta mendesain/membangun homestay dan sebagian pemilik memiliki keterampilan menyelam maupun berbahasa inggris untuk mendukung usaha homestay yang dikelola. Berdasarakan hasil observasi di lapangan dilihat dari derajat kesehatan masyarakat, kesehatan komunitas pemilik homestay di kedua kampung masih rendah karena fasilitas MCK milik umum dan fasilitas kesehatan dan tenaga medis kurang memadai. Sanitasi air untuk kebutuhan sehari-hari menggunakan mata air atau sumur galian yang juga terbatas sehingga untuk mandi biasanya menggunakan air yang tercampur dengan air payau. Tabel 5 menyajikan informasi modal SDM komunitas Pemilik homestay Raja Ampat dari kedua kampung.

Tabel 5 Modal SDM komunitas homestay Raja Ampat (Kampung Yenbuba dan Kampung Arborek), 2020

\begin{tabular}{ll}
\hline Indikator & Keterangan \\
\hline Tingkat pendidikan & Rendah, umumnya tamat SD \\
$\begin{array}{l}\text { Akses Terhadap } \\
\text { Pendidikan }\end{array}$ & $\begin{array}{l}\text { Rendah, Fasilitas Pendidikan hanya sampai tingkat SD dan terbatasnya } \\
\text { tenaga pendidik } \\
\text { Kapasitas SDM }\end{array}$ \\
$\begin{array}{l}\text { Cukup, komunitas mempunyai kemampuan manajemen SDM, } \\
\text { manajemen promosi, manajemen keuangan, dan manajemen operasional } \\
\text { walaupun sistemnya masih sederhana }\end{array}$ \\
$\begin{array}{l}\text { 25 Keluarga dari Kampung Yenbuba dan 13 Keluarga dari Kampung } \\
\text { Jumlah SDM yang }\end{array}$ & $\begin{array}{l}\text { Arborek mengelola usaha homestay } \\
\text { mengelola homestay }\end{array}$
\end{tabular}




\begin{tabular}{ll}
\hline Indikator & Keterangan \\
\hline Derajat Kesehatan & Rendah, sanitasi dan fasilitas kesehatan kurang \\
Usia & Umumnya berada pada usia produktif \\
\hline
\end{tabular}

5. Modal Lingkungan

Modal lingkungan merupakan modal di mana lingkungan dapat juga berupa potensi yang belum diolah dan mempunyai nilai ekonomi yang tinggi serta mempunyai nilai yang tinggi dalam upaya pelestarian alam dan juga kenyamanan hidup. Modal sumber daya alam (SDA) komunitas homestay Raja Ampat (Kampung Yenbuba dan Kampung Arborek) dalam penelitian ini dilihat dari: jenis potesi SDA dimiliki, kualitas lingkungan, status lahan, akses terhadap SDA, potensi rawan bencana. Hasil penilaian terhadap modal SDA disajikan pada tabel 6.

Tabel 6 Modal sumberdaya alam komunitas homestay Raja Ampat (Kampung Yenbuba dan Kampung Arborek), 2020

\begin{tabular}{|c|c|}
\hline Indikator & Keterangan \\
\hline Jenis potesi SDA dimiliki & Sumber daya alam, berupa perikanan, perkebunan, dan terumbu karang \\
\hline Kualitas lingkungan & $\begin{array}{l}\text { Kualitas lingkungan baik karna telah menjadi wilayah konservasi, } \\
\text { tetapi masih ditemukan sampah-sampah di lautan }\end{array}$ \\
\hline Status lahan & $\begin{array}{l}\text { Lahan milik masyarakat tetapi belum disahkan dalam bentuk sertifikat } \\
\text { lahan. Lahan ditentukan dari keputusan adat dan keputusan bersama } \\
\text { masyarakat atau keluarga. }\end{array}$ \\
\hline Akses terhadap SDA & $\begin{array}{l}\text { Masyarakat/pelaku usaha wisata dapat mengakses daerah-darerah yang } \\
\text { telah ditentukan sebagai tempat wisata berdasarkan peraturan yang } \\
\text { dibuat oleh pemerintah untuk wilayah konservasi. }\end{array}$ \\
\hline Potensi rawan bencana & $\begin{array}{l}\text { Potensi rawan bencana saat gelombang angin selatan di bulan April - } \\
\text { Juli }\end{array}$ \\
\hline
\end{tabular}

6. Modal Sosial

Modal sosial merupakan norma dan aturan yang mengikat warga masyarakat yang ada didalamnya, dan mengatur pola perilaku warga, juga unsur kepercayaan (trust) dan jaringan (networking) antar warga masyarakat ataupun kelompok masyarakat. Modal sosial komunitas homestay Raja Ampat dalam penelitian ini dilihat dari: jejaring komunitas, spiritulisme/sistem kepercayaan, budaya gotongroyong, sistem norma dan nilai yang disepakati dan ditaati, tingkat rasa kepercayan antar warga. Hasil penilaian terhadap modal sosial disajikan pada Tabel 7.

Tabel 7 Modal Sosial komunitas homestay Raja Ampat (Kampung Yenbuba dan Kampung Arborek), 2020

\begin{tabular}{ll}
\hline Indikator & Keterangan \\
\hline Jejaring komunitas & $\begin{array}{l}\text { Tingkat Jejaring komunitas homestay Raja Ampat mencapai level } \\
\text { internasional. Hal ini dikarenakan jejaring dari lembaga seventythree } \\
\text { yang memiliki cakupan skala pemasaran hingga internasional. }\end{array}$ \\
& $\begin{array}{l}\text { Modal spiritualisme dilihat dari agama yang dianut oleh masyarakat. } \\
\text { Spiritulisme/sistem }\end{array}$ \\
Kepercayaan & $\begin{array}{l}\text { Kristen Protestan yang taat dan menjadikan agama sebagai dasar dari } \\
\text { kehidupan sehari-hari. }\end{array}$ \\
Budaya gotongroyong & $\begin{array}{l}\text { Budaya gotong-royong kampung cukup baik, karena jumlah } \\
\text { penduduk setiap kampung yang sedikit dan saling terhubung dalam }\end{array}$ \\
& $\begin{array}{l}\text { ikatan keluarga. } \\
\text { Sistem norma dan nilai yang disepakati, ditaati, dan diyakini dalam }\end{array}$ \\
& Sistem adat masih cukup baik. Pengaruh budaya dan literasi dari luar \\
\hline
\end{tabular}




\begin{tabular}{ll}
\hline Indikator & Keterangan \\
\hline nilai yang disepakati & $\begin{array}{l}\text { yang masuk menjadi alasan pergeseran hukum adat di lingkup } \\
\text { masyarakat. }\end{array}$ \\
$\begin{array}{l}\text { Tingkat kepercayan antar } \\
\text { warga }\end{array}$ & $\begin{array}{l}\text { Tingkat kepercayaan komunitas sudah cukup terbuka walaupun } \\
\text { tingkat kepercayaan ini lebih kuat antar keluarga atau pemilik nama } \\
\text { marga yang sama. Untuk kepercayaan terhapat pendatang cenderung } \\
\text { tertutup. }\end{array}$
\end{tabular}

Berdasarkan hasil observasi dan wawancara di lokasi penelitian ditemukan hasil bahwa jerajaring yang dimiliki komunitas sudah masuk dalam level internasional karena pariwisata Raja Ampat mendatangkan lebih banyak wisatawan mancanegara. Sistem kepercayaan, norma, sifat gotong-royong masih cukup kuat karena kepercayaan pada spiritual dan adat istiadat yang masih tinggi. Tingkat kepercayaan masyarakat cukup tinggi jika berkaitan dengan hubungan antara sesama marga tetapi jika berbeda marga maka tingkat kepercayaannya cukup rendah.

\section{Klasifikasi Usaha Komunitas Homestay Raja Ampat}

Perkembangan usaha homestay di Kabupaten Raja Ampat berdampak signifikan pada pertumbuhan ekonomi masyarakat lokal, hal ini menjadi fokus pemerintah Kabupaten Raja Ampat untuk menjadikan usaha homestay sebagai usaha yang perlu didukung oleh pemerintah. Adapun tipologi homestay berdasarkan jenis bungalow dibagi kedalam 4 jenis yaitu bungalow tipe room in bungalow, tipe private bungalow, tipe VIP bungalow tipe 1 dan VIP bungalow tipe 2. Tipe bungalow-bungalow ini dibedakan dari material bangunan yang digunakan juga fasilitas yang ada di dalam bungalow.

Pada Awal tahun 2020, Pemerintah Kabupaten Raja Ampat menetapkan usaha homestay sebagai bagian dari UMKM dan berada di bawah pengawasan dan juga tanggung jawab dari Dinas Koperasi dan Usaha Kecil dan Menengah. Dalam Penelitian ini, peneliti mengklasifikasi usaha homestay di Kampung Yenbuba dan Kampung Arborek dalam 3 skala usaha yang dilihat dari modal aset. Dalam Penelitian ini, Dari hasil FGD peneliti mengklasifikasi usaha homestay Raja Ampat dalam 3 skala usaha yaitu, pemilik skala mikro, pemilik skala kecil, dan pemilik skala menengah. Skala usaha homestay diidentifikasi melalui beberapa indikator yaitu berdasarkan modal sosial yang sudah diidentifikasi dan Undang-Undang No. 20 Tahun 2008 tentang usaha mikro, kecil dan menengah berdasarkan besarnya modal/aset.

\section{Pemilik Skala Mikro}

Pemilik homestay skala mikro berdasarkan Undang-Undang No. 20 tahun 2008 adalah usaha homestay yang memiliki kekayaan bersih atau modal paling tinggi 50 juta dan omset paling tinggi di angka 300 juta. Jika dilihat dari modal atau aset, dalam membangun sebuah bungalow beserta dengan isinya di perlukan modal 10-15 juta. Pemilik homestay dengan jumlah 1-3 bungalow dengan bentuk rumah lokal yang terbuat dari kayu, dinding daun bobo, dan atap daun sagu serta kamar mandi luar masuk dalam klasifikasi pemiliki usaha mikro.

Tabel 8 Identifikasi pemilik skala mikro Kampung Yenbuba dan Kampung Arborek, 2020

\begin{tabular}{ll}
\hline Indikator & Keterangan \\
\hline $\begin{array}{l}\text { Skala aset dan } \\
\text { pengelolaan }\end{array}$ & - Memiliki 1 - 3 bungalow kapasitas dengan fasilitas tempat tidur, \\
& meja, kipas angin, kelambu serta kamar mandi luar \\
Besar nya modal & Tidak memiliki moda transportasi \\
Jaringan Usaha & $15-45$ juta tergantung banyaknya bungalow \\
& - Tergabung dalam asosiasi dan melakukan promosi melalui website \\
& stayrajaampat.com \\
& - Kegiatan promosi melalui sosial media khususnya facebook dan \\
& instagram \\
Bentuk-bentuk & Antar jemput dari waisai ke homestay dan homestay ke waisai \\
\hline
\end{tabular}




\begin{tabular}{ll}
\hline Indikator & Keterangan \\
\hline pelayanan & dengan lonboat atau speedboat (sewa). \\
& - Makan 3x sehari (pagi, siang dan malam) dalam bentuk prasmanan \\
& - Wisata snorkeling di sekitar pulau \\
& - Wisata landscape di sekitar pulau \\
Pendapatan & Rp 10 juta -25 juta dan bisa mencapai 40 jt saat musim liburan dari \\
& hasil sewa homestay $350-450$ ribu per orang dengan rata-rata 200 juta \\
& per tahun \\
Pengeluaran 5 juta -15 juta setiap bulan untuk keperluan logistik, air, bensin, dan & penggantian bahan bangunan yang rusak
\end{tabular}

\section{Pemilik Skala Kecil}

Pemilik homestay skala kecil berdasarkan Undang-Undang No. 20 tahun 2008 adalah usaha homestay yang memiliki kekayaan bersih atau modal 50 - 500 juta dengan omset di angka 300 juta $-2,5$ miliar.

Tabel 9 Identifikasi pemilik skala kecil Kampung Yenbuba dan Kampung Arborek, 2020

\begin{tabular}{|c|c|}
\hline Indikator & Keterangan \\
\hline $\begin{array}{l}\text { Skala Aset dan } \\
\text { Pengelolaan }\end{array}$ & $\begin{array}{l}\text { - Memiliki } 4 \text { - } 10 \text { bungalow dengan jenis privat bungalow dan VIP } \\
\text { bungalow (kamar mandi dalam) } \\
\text { - Memiliki moda transportasi longboat atau speedboat } \\
\text { - Memiliki Gazebo atau restaurant }\end{array}$ \\
\hline Besarnya modal & $>50$ juta \\
\hline Jaringan Usaha & $\begin{array}{l}\text { - Tergabung dalam asosiasi dan melakukan promosi melalui website } \\
\text { stayrajaampat.com } \\
\text { - Kegiatan promosi melalui sosial media khususnya facebook dan } \\
\text { instagram } \\
\text { - Promosi melalui Aplikasi online seperti Traveloka, Booking.com, } \\
\text { Tiket.id, dan platform lainnya }\end{array}$ \\
\hline $\begin{array}{l}\text { Bentuk-bentuk } \\
\text { pelayanan }\end{array}$ & $\begin{array}{l}\text { - Antar jemput dari waisai ke homestay dan homestay ke Waisai } \\
\text { dengan longboat atau speedboat (sewa). } \\
\text { - Makan 3x sehari (pagi, siang dan malam) dalam bentuk prasmanan } \\
\text { - Wisata snorkeling dan diving } \\
\text { - Wisata landscape di sekitar pulau } \\
\text { - Transportasi ke lokasi-lokasi wisata umumnya diving dan akan } \\
\text { ditemani oleh tourguide lokal yang telah berlisensi openwater dan } \\
\text { fasih berbahasa inggris. }\end{array}$ \\
\hline Pendapatan & $\begin{array}{l}\text { Rp } 40 \text { juta - } 80 \text { juta dan bisa mencapai } 120 \text { juta saat musim liburan dari } \\
\text { hasil sewa homestay } 350 \text { - } 550 \text { ribu per orang dengan rata-rata } 800 \text { juta } \\
\text { per tahun }\end{array}$ \\
\hline Pengeluaran & $\begin{array}{l}20-60 \text { juta setiap bulan untuk keperluan logistik, air, bensin, dan } \\
\text { penggantian bahan bangunan yang rusak dan perawatan } \\
\text { longboat/speedboat. }\end{array}$ \\
\hline
\end{tabular}




\section{Pemilik Skala Menengah}

Pemilik homestay skala menengah berdasarkan Undang-Undangg No 20 tahun 2008 adalah usaha homestay yang memiliki kekayaan bersih atau modal 500 Juta - 10 miliar dengan omset di angka 2,5 miliar - 50 miliar.

Tabel 10 Identifikasi Pemilik Skala Menengah Kampung Yenbuba dan Kampung Arborek, 2020

\begin{tabular}{|c|c|}
\hline Indikator & Keterangan \\
\hline $\begin{array}{l}\text { Skala Aset dan } \\
\text { Pengelolaan }\end{array}$ & $\begin{array}{l}\text { - Memiliki > } 6 \text { bungalow dengan jenis privat bungalow dan VIP } \\
\text { bungalow (kamar mandi dalam) } \\
\text { - Memiliki moda transportasi speedboat lebih dari satu } \\
\text { - Memiliki Gazebo atau restoran } \\
\text { - Memiliki dive center } \\
\text { - Memiliki Liveonboard }\end{array}$ \\
\hline Besar nya modal & $>500$ juta \\
\hline Jaringan Usaha & $\begin{array}{l}\text { - Tergabung dalam asosiasi dan melakukan promosi melalui website } \\
\text { stayrajaampat.com } \\
\text { - Kegiatan promosi melalui sosial media khususnya facebook dan } \\
\text { instagram } \\
\text { - Promosi melalui aplikasi online seperti Traveloka, Booking.com, } \\
\text { Tiket.id, dan platform lainnya }\end{array}$ \\
\hline $\begin{array}{l}\text { Bentuk-bentuk } \\
\text { pelayanan }\end{array}$ & $\begin{array}{l}\text { - Antar jemput dari waisai ke Homestay dan Homestay ke Waisai } \\
\text { dengan longboat atau speedboat (sewa). } \\
\text { - Makan 3x sehari (pagi, siang dan malam) dalam bentuk prasmanan } \\
\text { - Wisata snorkeling dan diving } \\
\text { - Wisata landscape di sekitar pulau } \\
\text { - Transportasi ke lokasi-lokasi wisata umumnya diving dan akan } \\
\text { ditemani oleh tourguide diving lokal yang telah berlisensi openwater } \\
\text { dan fasih berbahasa inggris. }\end{array}$ \\
\hline Pendapatan & $\begin{array}{l}>80 \text { juta dan bisa mencapai } 200 \text { juta saat musim liburan dari hasil sewa } \\
\text { homestay } 350-550 \text { ribu per orang dengan rata-rata }>1 \text { miliar per tahun }\end{array}$ \\
\hline Pengeluaran & $\begin{array}{l}>30 \text { juta setiap bulan untuk keperluan logistik, air, bensin, dan } \\
\text { penggantian bahan bangunan yang rusak, perawatan longboat/speedboat, } \\
\text { dan alat-alat snorkeling serta diving. }\end{array}$ \\
\hline
\end{tabular}

$\overline{\text { Berdasarkan Undang-Undang No } 20 \text { tahun } 2008 \text { Pemilik homestay skala mikro adalah usaha homestay }}$ yang memiliki kekayaan bersih atau modal paling tinggi 50 juta. Jika dilihat dari modal atau aset, dalam membangun sebuah bungalow beserta dengan isinya di perlukan modal 10-15 juta. Pemilik homestay skala kecil adalah usaha homestay yang memiliki kekayaan bersih atau modal $50-500$ juta. Pemilik homestay skala menengah yaitu usaha homestay yang memiliki kekayaan bersih atau modal 500 Juta - 10 miliar. Terdapat total 112 Pemilik homestay di Raja Ampat. Pada data menunjukan terdapat 25 homestay dari Kampung Yenbuba dan13 homestay dari Kampung Arborek, adapun rincian skala usaha homestay pada kedua kampung penelitian pada Gambar 3. 


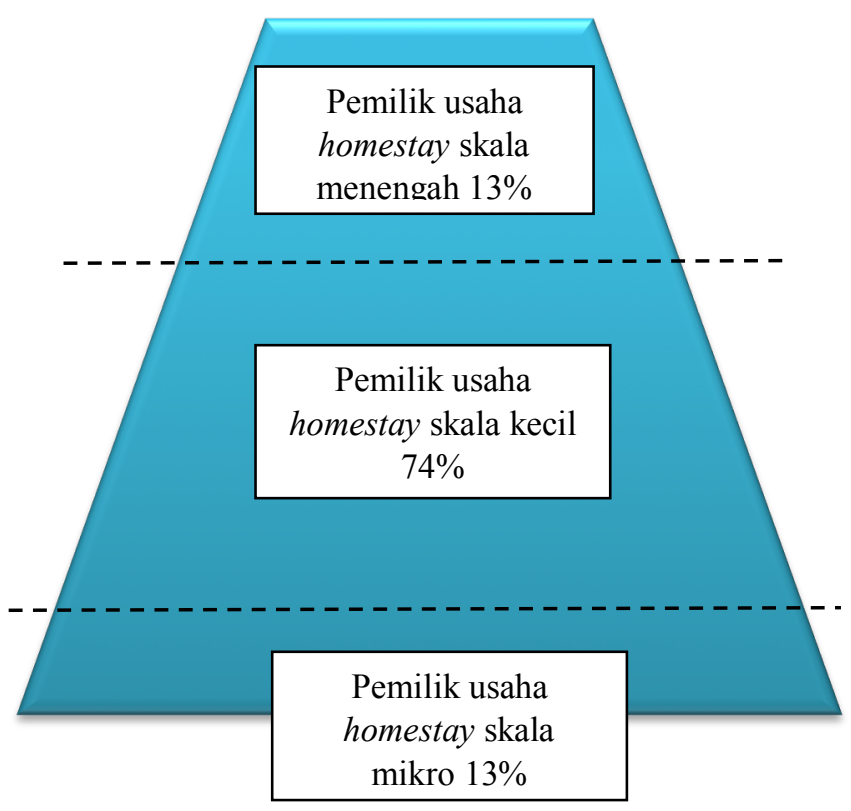

Data berdasarkan hasil wawancara, observasi dan Undang-Undang Republik Indonesia No. 20 Tahun 2008

- Skala Menengah: total 5 homestay dengan modal atau aset kekayaan 500 Juta - 10 miliar, yaitu: 3 homestay Kampung Yenbuba dan 2 homestay Kampung Arborek

- Skala Kecil: terdapat total 28 homestay dengan modal 50 - 500 juta, yaitu: 19 homestay Kampung Yenbuba dan 9 Homestay Kampung Arborek

- Skala Mikro: total 5 homestay dengan modal atau aset kekayaan $<50$ juta yaitu: 2 homestay Kampung Yenbuba dan 3 homestay Kampung Arborek

Gambar 4. Klasifikasi usaha homestay Kampung Yenbuba dan Kampung Arborek.

\section{Intervensi Pihak Luar dan Akses Pembiayaan}

Dalam mengimplementasikan pembangunan berbasis masyarakat atau community based development pada sektor pariwisata perlu melibatkan pihak luar seperti pemerintah, lembaga swadaya masyarakat (LSM), masyarakat sekitar dan juga pihak swasta. Dalam Björk (2000) mengemukakan setidaknya ada empat kelompok yang harus bekerja sama dalam pengelolaan pariwisata yang berkelanjutan. Empat kelompok tersebut meliputi masyarakat lokal, pihak berwenang, wisatawan dan perusahaan yang terlibat dalam pariwisata.

Intervensi pemerintah dalam pengembangan pariwisata, yaitu dalam bentuk kebijakan-kebijakan untuk memberikan kemudahan dalam mendapatkan akses terhadap berbagai sumberdaya yang dimiliki, pihak LSM dalam peningkatan kapasitas masyarakat, serta partisipasi pihak swasta dalam bentuk pendanaan dan bantuan material lainnya. Pembanguan sektor pariwisata yang berbasis komunitas atau masyarakat memberikan kontribusi dalam upaya pengurangan kemiskinan di wilayah tersebut (Latuconsina et al., 2019). Dari hasil FGD di identifikasikan stakeholder yang terlibat dan memilki peran dalam dinamika sosial masyarakat Raja Ampat, sebagai berikut:

\section{Lembaga Swadaya Masyarakat}

\section{Lembaga CI Indonesia}

Conservation International (CI) Indonesia merupakan lembaga swadaya masyarakat yang terdapat di Raja Ampat. CI Indonesia berperan mendamping masyarakat dalam upaya menjaga dan mengelola sumber daya alam sekitar. Pada tahun 2001 CI Indonesia melakukan pendekatan kepada masyarakat Raja Ampat untuk melakukan sosialisasi: 1) Menjaga biota laut dan terumbu karang; 2) penanaman mangrove; 3)pengelolaan sumber daya berkelanjutan; dan 4) pengembangan potensi. CI Indonesia bersama dengan dinas pariwisata Raja Ampat juga melakukan peningkatan kesadaran masyarakat terhadap kekayaan potensi alam yang mampu meningkatkan ekonomi masyarakat dengan cara membuka peluang bisnis ekowisata salah satunya dengan Homestay.

Conservation Internasional (CI) Indonesia Selama lebih dari 5 tahun melakukan pendekatan kepada masyarakat di wilayah utara Raja Ampat memberikan edukasi tentang pentingnya menjaga alam dan mengubah kebiasaan hidup masyarakat yang berpotensi pada tindakan mengeksploitasi sumberdaya alam seperti penggunaan potas/bom yang merusak habitat terumbu karang, konsumsi penyu dalam jumlah besar setiap perayaan adat, penangkapan ikan-ikan yang dilindungi dan sebagainya. Conservation Internasional (CI) Indonesia juga memberikan pandangan-pandangan, pengetahuan dan arahan tentang bagaimana menjaga alam dengan baik dan justru akan membuka peluang peningkatan ekonomi dengan cara menciptakan usaha di bidang pariwisata. CI Indonesia juga bekerjasama dengan 
pemerintah daerah dan masyarakat dalam upaya peningkatan potensi sumber daya alam dan manusia, dan upaya konservasi dalam mencapai pariwisata berkelanjutan Raja Ampat dengan cara membentuk kelompok sadar wisata.

\section{Seventythree (Lembaga 73)}

Pada tahun 2013 Seventythree mitra dari Walton Family Foundation sebagai bagian dari Bird's Head Seascape I bekerjasama dengan Starling Resources dan mitra lainnya sebagai bagian dari proyek untuk memastikan keberlanjutan politik, sosial dan ekonomi Kawasan Konservasi Laut (KKL) yang dikendalikan secara lokal agar berfungsi, dan untuk meningkatkan kehidupan masyarakat Raja Ampat.

Seventythree mengunjungi masyarakat lokal dan menjalankan proyek memperkuat kapasitas pengusaha lokal yang memiliki dan mengoperasikan homestay di kepulauan Raja Ampat. Di tahun 2013 untuk mendukung pengembangan usaha homestay masyarakat lokal, Seventythree melakukan pelatihan bisnis model kanvas dan juga membentuk perkumpulan atau komunitas pelaku dan pemilik usaha homestay yang berada di selat dampier dan di beri nama Asosiasi Usaha Homestay Lokal Kabupaten Raja Ampat atau yang sering disebut Asosiasi Homestay Raja Ampat. Selain pembentukan asosiasi, Seventythree juga memfasilitasi asosiasi homestay dengan website www.stayrajaampat.com sebagai media promosi online untuk menarik pasar internasional. Setiap pemilik Homestay yang bergabung dalam asosiasi, maka homestay nya akan di pasarkan dalam website dengan kesepakatan dibebankan biaya 15 persen dari hasil sewa homestay kepada wisatawan. Biaya 15 persen ini nantinya digunakan untuk membayar pengurus asosiasi dan juga biaya maintenance website.

Pada pelatihan pertama ini Seventythree memberikan arahan dan edukasi dalam melakukan usaha wisata dan menjadikan masyarakat lokal mandiri secara financial. Tidak hanya edukasi mengenai bagaimana cara berbisnis Seventythree bersama masyarakat juga bersama-sama menjaga lingkungan khususnya lingkungan bawah laut sebagai aset dan daya tarik wisatawan untuk datang berkunjung ke Raja Ampat. Setiap pemilik usaha homestay yang tergabung dalam asosiasi akan diberikan pelatihan mengenai manajemen bisnis, hospitality, dan pengelolaan situs web Asosiasi homestay Raja Ampat Environment Watch untuk memfasilitasi pelaporan tentang setiap insiden eksploitasi di darat atau laut.

Dengan hadirnya Seventythree untuk mendampingi masyarakat dengan komunitas adat Raja Ampat pemilik homestay lokal, kelompok perempuan, kepala desa dan dewan, gereja dan pemuda yang sekarang diwakili oleh Asosiasi homestay Lokal Raja Ampat dalam kelestarian alam dan membangun peluang bisnis yang sejalan beriringan dengan konservasi alam merubah cara pandang masyarakat lokal Raja Ampat yang sebelumnya tidak punya pilihan selain mencari nafkah dari penangkapan ikan dengan bom, penebangan kayu ilegal dan perdagangan satwa liar untuk bertahan hidup dan menyekolahkan anak-anak mereka. Dalam waktu 3 tahun masyarakat selat dampier telah membangun sektor yang menghasilkan pendapatan kotor sekitar USD 1,5 juta per tahun dan yang telah menciptakan setidaknya 600 pekerjaan lokal baru di homestay, perikanan dan pertanian.

Kelompok Pemerintah

\section{Pemerintah Kampung}

Sebagian besar masyarakat menggantungkan perekonomian pada bidang pariwisata. Hal ini menjadi fakus pemerintah kampung dalam mendukung kemajuan perekonomian masyarakat. Kepala Kampung dan sebagian besar aparat kampung di kedua kampung penelitian merupakan pemilik usaha Homestay. Dalam meningkatkan keberdayaan ekonomi masyarakat setiap tahunnya di setiap kampung melakukan Musrenbang untuk menentukan program kerja yang akan dilaksanakan dengan dana kampung. Pemerintah kampung mendapatkan dana desa setiap tahunnya untuk dimanfaatkan dalam menjalaknkan BumDes.

Kampung Yenbuba mengalokasikan dana kampung untuk membuat BumDes Mart yang menyediakan berbagai kebutuhan sehari-hari masyarakat, nyatanya dengan adanya BumDes Mart ini tidak mampu untuk menaikkan perekonomian warga dan pada akhirnya produk-produk yang di jual BumDes Mart habis di ambil warga dengan alasan pinjam dan akhirnya tidak berjalan kembali. Setelah program BumDes Mart Tidak berhasil di Kampung Yenbuba menyepakati untuk dana desa setiap tahunnya di berikan kepada warga secara bergilir untuk kebutuhan seperti pembelian longboat atau mesin longboat/speedboat. 
Kampung Arborek mengalokasikan dana kampung menjadi BumDes yang bermitra dengan BNI, di kelola dan di supply oleh warga dari waisai untuk penyediaan logistik, fasilitas keuangan seperti transfer, pembayaran listrik, isi ulang pulsa dan lain-lain. Bumdes Arborek juga menjadi alternatif pemilik usaha homestay untuk mendapatkan pasokan logistik dan bahan bakar tanpa harus datang ke Waisai dan dengan harga yang sama dengan yang dijual di Waisai.

\section{Dinas Pariwisata dan Kebudayaan Kabupaten Raja Ampat}

Dinas Pariwisata dan Kebudayaan Kabupaten Raja Ampat merupakan dinas yang bertanggung jawab terhadap pengelolaan pariwisata di Kabupaten Raja Ampat. Melihat peluang wisata di kepulauan Raja Ampat, Dinas Pariwisata dan Kebudayaan Kabupaten Raja Ampat melakukan berbagai pembinaan pariwisata kepada masyarakat lokal Raja Ampat. Pembinaan tersebut dilakukan dalam bentuk pelatihan-pelatihan, seperti pelatihan standar pelayanan homestay, pelatihan pemberdayaan perempuandalam bidang usaha kecil dan keterampilan, pelatihan dan sertifikasi diving, serta mengadakan studi banding dan workshop ke singapore. Dinas Pariwisata dan Kebudayaan juga memberikan bantuan sebesar 1 Milyar dalam bentuk barang dengan meminta bantuan Asosiasi untuk menentukan kebutuhan apasaja yang diperlukan oleh pemilik homestay. Bantuan tersebut pada akhirnya direalisasikan pada tahun 2017 dalam bentuk kasur, selimut, bantal, dan peralatan lain yang menunjang, yang dibantu pengalokasiannya oleh asosiasi Homestay Raja Ampat.

Di tahun 2009, Dinas Pariwisata dan Kebudayaan bersama pemerintah daerah Kabupaten Raja Ampat menghibahkan Homestay dengan fasilitas 2 bungalow yang dikelola bersama di Kampung Arborek. homestay tersebut diberikan sebagai homestay percontohan yang saat ini sudah dikelola secara pribadi oleh Bapak Nomensen Mambraku. Pada tahun 2020, Dinas Pariwisata membentuk tim IT (Informasi dan Teknologi) untuk membuat website sebagai media promosi dan booking homestay yang nantinya seluruh homestay Raja Ampat akan di promosikan dalam website tersebut dan dikelola oleh Dinas Pariwisata dan Kebudayaan.

\section{Dinas Koperasi dan UKM Kabupaten Raja Ampat}

Pada awal tahun 2020 Homestay di kabupaten Raja Ampat masuk dalam kategori UKM dan menjadi tanggung jawab Dinas Koperasi dan UKM Kabupaten Raja Ampat dalam memfasilitasi dan mendukung kegiatas usaha Homestay masyarakat lokal. Langkah awal yang dilakukan oleh Dinas Koperasi dan UKM adalah mendata seluruh homestay di kabupaten Raja Ampat dan mengalokasikan bantuan berupa dana 1 Milyar untuk mendukung para pelaku usaha Homestay. Bantuan tersebut diberikan kepada masyarakat yang sudah membentuk kelompok usaha dan ingin mencoba membangun usaha homestay. Dari dana 1 Milyar tersebut akan diberikan kepada 5 kelompok dengan masing-masing kelompok mendapatkan bantuan berupa Homestay seharga 200 Juta. Penentuan kelompok penerima homestay ini dilakukan dengan cara seleksi proposal yang sudah masuk, dan untuk seluruh pengerjaan homestay dari design, proses membangun hingga fasilitas peralatan penunjang lainnya akan dilakukan oleh dinas koperasi dan UKM.

Pihak Swasta

\section{Bank Negara Indonesia (BNI)}

Pada tahun 2016 Bank Negara Indonesia (BNI) melalui Program Corporate Sosial Responsibility (CSR) menjadikan Kampung Arborek sebagai Kampung Binaan BNI yang diberi nama Kampung BNI Wisata Arborek. Pada Program CSR ini BNI memberi bantuan berupa fasilitas bangunan gapura dan gazebo yang diperuntukan untuk mendukung kenyamanan wisatawan yang datang. Selain memberikan bantuan fasilitas bangunan, BNI juga mendorong pertumbuhan kredit tanpa agunan (KTA) melalui penyaluran kredit kepada Usaha Kecil Menengah (UKM) yang belum bankable. Program KTA ini di tujukan kepada para pelaku UKM khususnya di bidang pariwisata untuk mendapatkan pinjaman dengan mudah. Pinjaman yang di berikan berkisar dari Rp. 15.000.000 hingga Rp. 30.000.000 dengan ketentuan angsuran dilakukan dengan tenor 36 bulan ( 3 tahun) dengan bunga sebesar $6 \%$ setiap tahunnya.

Program KTA ini hanya diberikan kepada masyarakat Kampung Arborek. Program ini pun tidak bekerjasama dengan asosisasi Homestay Raja Ampat. Siapapun pelaku UKM di Kampung Arborek yang ingin melakukan pinjaman bisa langsung mendapatkan pinjaman tersebut dari Bank BNI. Sebagian besar pemilik homestay Kampung Arborek mengajukan pinjaman dan dijelaskan pada tabel berikut: 


\begin{tabular}{lllll}
\hline No & Pemilik & Nama Homestay & Jumlah Kamar & Sumber Modal \\
\hline 1 & Rakibu Mambrasar & Arborek & 10 & Pribadi + BNI \\
2 & Nonmensen & Manta & 7 & Pemda + Pribadi \\
& Mambraku & & \\
3 & Kilion Mambrasar & Tenggiri & 6 & BNI + Pribadi \\
4 & Stvanus Mambraku & Kalabia & 3 & BNI \\
5 & Philipus Mambrasar & Mambrayub & 22 & Swasta + Pribadi \\
6 & Naftali Mambraku & Mawar & 12 & BNI + Pribadi \\
7 & Marlon Mambrasar & Lolosi/ Blue Shark & 8 & BNI + Pribadi \\
8 & Eki Mambrasar & Kayafyof & 8 & BNI + Pribadi \\
9 & Yance Mambrasar & Worisun & 5 & BNI + Pribadi \\
10 & Enos Rumbewas & Bewas & 2 & BNI \\
11 & Yulius Mamrasar & Raja Ampat Sunset & 4 & Pribadi \\
12 & Buce Mambrasar & Indip & 3 & Pribadi \\
13 & Mika Mambrasar & Mambers & 4 & Pribadi \\
\hline
\end{tabular}

Dari 13 Homestay yang terdata di Kampung Arborek sebanyak 8 homestay melakukan pinjaman. Dari hasil wawancara dengan para pemilik homestay yang masuk salam anggota asosiasi, rata-rata anggota mengajukan pinjaman sebesar Rp. 20.000.000 yang di gunakan untuk modal membangun 2 bungalow tambahan atau membeli longboat untuk digunakan sebagai alat transportasi wisatawan. Program pinjaman KUR dari BNI ini dilakukan sebanyak 2 kali yaitu pada tahun 2016 dan tahun 2018

2. Yayasan Barefoot

Yayasan konservasi Barefoot yang berada di bawah PT Ayo Raja Ampat. Yayasan Konservasi Barefoot merupakan yayasan yang menyediakan membuka lowongan volunteer dengan kegiatan community dan science. Yayasan Barefoot memberikan bantuan berupa penambagan jumlah bungalow milik salah satu warga Arborek yaitu homestay Mambrayub. Penambahan bangunan bungalow di homestay Mambrayub hingga mencapai 22 kamar dan homestay tersebut disewa oleh yayasan Barefoot untuk dijadikan camp dan tempat volunteer menginap. Kegiatan yang dilakukan oleh Barefoot di Kampung Arborek adalah mengumpulkan volunteer untuk melakukan kegiatan seperti mengajar, kegiatan beach clean up, para volunteer juga bisa melakukan diving dan mengekspolrasi Raja Ampat dan melakukan kegiatan science yang berkaitan dengan konservasi laut.

\section{Dinamika Masyarakat Merespon Intervensi}

Dinamika masyarakat merupakan perubahan sosial yang terjadi pada masyarakat yang mencakup perubahan dalam aspek-aspek struktur dari suatu masyarakat, ataupun karena terjadinya perubahan dari faktor lingkungan, sistem hubungan sosial, ekonomi maupun budaya (Sumartono, 2020). Keberhasilan dinamika masyarakat merespon intervensi ditunjukan dengan adanya perubahan profesi masyarakat yang awalnya adalah nelayan dengan menggunakan bom dan potas, menebang pohon secara ilegal, dan menangkap satwa langka dan dilindungi beralih menjadi pengelola pariwisata. Perubahan sosial ini sangat berpengaruh pada perilaku masyarakat lokal yang melindungi alam, mempertahankan lahan miliki mereka, peningkatan kapasitas serta peningkatan ekonomi. Intervensi pihak luar menjadi penting dapat menjadi faktor kegagalan ataupun keberhasilan dinamika sosial dalam mencapai pengembangan masyarakat yang berkelanjutan. Dinamika atau perubahan masyarakat dapat terjadi karena beberapa faktor menurut Salam dalam Tejokusumo (2014), antara lain:

1. Penyebaraan informasi, meliputi pengaruh dan mekanisme media dalam menyampaikan pesanpesan ataupun gagasan (pemikiran)

2. Modal, antara lain sumber daya manusia ataupun modal finansial 
3. Teknologi, suatu unsur dan sekaligus faktor yang cepat berubah sesuai dengan perkembangan ilmu pengetahuan

4. Ideologi atau agama, keyakinan agama atau ideologi tertentu berpengaruh terhadap porses perubahan sosial

5. Birokrasi, terutama berkaitan dengan berbagai kebijakan pemerintahan tertentu dalam membangun kekuasaannya

6. Agen atau aktor, hal ini secara umum termasuk dalam modal sumber daya manusia, tetapi secara spesifik yang dimaksudkan adalah inisiatif-inisiatif individual dalam "mencari" kehidupan yang lebih baik.

\section{Kendala}

\section{Kapasitas SDM}

Pengembangan kapasitas dan kemampuan (capacity building) merupakan peningkatan kinerja masyarakat secara optimal untuk menunjang pencapaian target pembangunan ekonomi, pembenahan SDM, meningkatkan kemampuan individu dalam rangka mewujudkan pengembangan kampung ekowisata berbasis masyarakat (Abdoellah et al., 2019). Kurangnya Pengetahuan manajemen pengelolaan dan keuangan, belum memiliki SOP, dan kurangnya keterampilan berbahasa asing menjadi kendala umum dalam pengelolaan usaha homestay di masyarakat.

\section{Akses Pemodalan}

Dari 38 homestay yang beradi di kedua kampung penelitian hanya 9 homestay yang memiliki akses pemodalan ke perbankan. 8 orang anggota adalah masyarakat kampung Arborek yang merupakan Kampung binaan BNI sehingga mendapatkan akses untuk mendapatkan pinjaman dan satu homestay lainnya merupakan milik warga Kampung Yenbuba yang berprofesi sebagai PNS sehingga dapat dengan mudah mendapatkan kredit pinjaman perbankan. Kurangnya pengetahuan akses pemodalan, rasa takut dan kekhawatiran untuk mengajukan pinjaman ke bank, tidak memiliki jaminan untuk melakukan pinjaman ke perbankan, dan akses perbankan yang jauh dari lokasi usaha. Percepatan pertumbuhan ekonomi berperan sebagai syarat dasar yang paling strategis bagi peningkatan kualitas kehidupan rakyat. Elemen penting dalam mendukung percepatan pertumbuhan ekonomi adalah mengoptimalkan kontribusi sektor keuangan dengan membuka akses layanan jasa keuangan seluas mungkin kepada masyarakat dan pelaku usaha seperti UMKM (Steelyana, 2013).

\section{Standarisasi kelayakan dan fasilitas homestay}

Sebagian besar homestay di Kampung Yenbuba dan Kampung Arboerek tidak memiliki alat dive sendiri, dan hanya terdapat 3 dive center yang berada di kedua kampung. Jika saat permintaan diving sedang meningkat, dive center di kedua kampung tidak dapat memenuhi permintaan wisatawan karena terbatasnya perlengkapan diving yang dimiliki. Selain itu, bentuk bangunan homestay yang umumnya terbuat dari kayu, dinding daun bobo dan atap daun sagu mudah rusak, fasilitas kamar mandi luar tidak nyaman, bentuk bangunan kurang aman seperti pintu dan jendela tidak bisa ditutup, belum adanya fasilitas layanan kesehatan dan dalam keadaan mendesak masih menggunakan fasilitas kesehatan di Papua Diving Resort serta belum adanya layanan informasi untuk wisatawan di sekitar lokasi wisata.

\section{Jaringan}

Jaringan (networking) menjadi salah satu kelemahan yang dimiliki oleh Asosiasi. Adanya Asosiasi seharusnya mampu menjadi media untuk bermitra dan membangun jaringan dengan pihak luar seperti pemerintahan, lembaga maupun swasta. Nyatanya selama berdiri dari tahun 2013, asosiasi hanya membangun jaringan dengan lembaga 73 dan CI Indonesia. Setiap ada program pemerintah maupun swasta, asosiasi jarang dilibatkan dalam pengalokasian program tersebut. Adanya bantuan dari bank maupun CSR perusahaan hanya akan melewati pemerintah daerah lalu melalui rekomendasi tersebut pihak swasta akan langsung terjun ke masyarakat tanpa melakukan pendekatan dengan asosiasi. Bantuan dana seperti dana hibah maupun pinjaman, para penerima dana tersebut biasanya di tentukan langsung oleh pemerintah. Hal ini lah yang membuat kurangnya kepercayaan asosiasi terhadap kinerja pemerintah. Lain halnya jika berkaitan dengan program pelatihan maupun pendampingan, asosiasi akan di libatkan dalam mengirimkan anggota-aggota mereka yang kiranya perlu untuk mendapatkan pelatihan-pelatihan tersebut. 


\section{Sinergi antar pelaku usaha}

Wisata Raja Ampat terkenal sebagai wisata mahal di Indonesia, hal ini dikarenakan biaya transportasi untuk mencapai ke destinasi wisata Raja Ampat sangat mahal. Dari sorong menuju Waisai (Ibukota Kabupaten Raja Ampat) di kenakan biaya sewa speedboat sebesar Rp.6.000.000 dan memakan waktu perjalanan 4-5 jam. Dari Waisai Ke kampung yang berada dikawasan Selat Dampier di kenakan biaya 1,2 jt untuk sekali perjalanan dengan speedboat dengan durasi 1,5-2 jam. Belum lagi sewa speedboat untuk mengunjungi lokasi-lokasi wisata dan lokasi selam selama beberapa hari berada di Raja Ampat. Berdasarkan hasil wawancara, pemilik homestay tidak menyediakan paket wisata karena belum memiliki mitra usaha untuk menyediakan segala kebutuhan wisatawan.

Sebagian besar pemilik homestay hanya menyediakan akomodasi, transportasi dan konsumsi, hanya beberapa pemilik homestay saja yang menyediakan semua kebutuhan tamu seperti alat selam dan tourguide bersertifikat openwater. Pengelola usaha wisata Kabupaten Raja Ampat tidak hanya pemilik homestay, tetapi juga pemilik dive center, pemilik moda transportasi, pemandu selam, dan pemilik usaha logistik. Kelemahan usaha homestay adalah, tidak memiliki sinergi dengan pelaku usaha lainnya sehingga segala sesuatu dikerjakan sendiri.

\section{Arah Pengembangan Usaha Komunitas Pemilik Homestay Raja Ampat}

Pengembangan usaha pariwisata di daerah wisata tentunya harus didasari pada perencanaan, arah pengembangan dan pengelolaan yang sudah dirancang agar semua potensi baik daerah maupun internal masyarakat dapat dikembangkan secara optimal dan tepat sasaran. Untuk mencapai arah pengembangan pariwisata yang berkelanjutan, perlu adanya keterlibatan dari berbagai pihak baik pemerintah, LSM maupun swasta. Lebih penting lagi adalah partisipasi dan keterlibatan masyarakat lokal sebagai salah satu faktor keberhasilan pengembangan pariwisata. Pembangunan melalui partisipasi masyarakat merupakan salah satu upaya untuk memberdayakan potensi masyarakat sekitar. (Hamsinah B, 2017).

Perkembangan UMKM masih terhambat sejumlah persoalan, yaitu pada segi pembiayaan, produksi, pemasaran, dan sumber daya manusia. Hasil identifikasi klasifikasi usaha homestay dan juga kendala yang dihadapi oleh komunitas pemilik Homestay menjadi latar belakang perancangan arah pengembangan usaha komunitas Homestay Raja Ampat khususnya di Kampung Yenbuba dan Kampung Arborek. Ada 3 hal yang menjadi fokus arah pengembangan dalam penelitian ini yaitu 1) Pembiayaan; 2) Peningkatan Kapasitas dan Penguatan kelembagaan 3) Konektivitas dan digitalisasi.

\section{Pembiyaan}

Pembiayaan atau pemodalan merupakan kebutuhan mutlak yang diperlukan oleh pelaku usaha homestay di Kampung Yenbuba dan Kampung Arborek. Kurangnya literasi keuangan dan terbatasnya akses terhadap lembaga keuangan menjadi permaslahan yang di hadapi komunitas dalam mengembangkan usahanya. Untuk menanggapi persoalan tersebut terutama dari segi permodalan dan pemasaran, terdapat satu model yang bernama "Inklusi Keuangan". Inklusi Keuangan merupakan upaya untuk mendorong sistem keuangan agar dapat diakses seluruh lapisan masyarakat, sehingga mendorong pertumbuhan ekonomi yang berkualitas sekaligus mengatasi kemiskinan. (Irmawati et al., 2013).

Dalam penelitian ini, lembaga keuangan yang di anggap sesuai untuk pembiayaan komunitas pemiliki homestay Raja Ampat yaitu adalah Lembaga Pembiyaan Dana Bergulir (LPDB). Lembaga keuangan ini dianggap tepat karena suku bunga yang rendah dan persyaratan yang lebih mudah daripada melakukan pinjaman ke lembaga keuangan perbankan. Dalam pembiayaa melalu LPDB perlu upayaupaya lebih terstruktur baik dari sisi penyaluran, skema pengembalian dana serta sistem monitoring dan evaluasi pemberian pembiayaan kepada para mitra (Nugroho \& Rusydiana, 2019). Hal awal yang akan dilakukan adalah dengan pembeuntukan koperasi pariwisata atau dengan menjadikan salah satu koperasi yang telah aktif minimal 1 tahun untuk menjadi wadah komunitas homestay untuk mendapatkan akses keuangan ke LPDB agar efektifitas pinjaman dana bergulir dapat dimanfaatkan secara lebih merata dan komprehensif.

\section{Peningkatan Kapasitas dan Penguatan kelembagaan}

Pelatihan mengenai bisnis wisata dan pelayanan sudah sering diadakan pihak luar baik oleh Pemerintah, LSM maupun swasta. Nyatanya pelatihan tersebut tidaklah cukup terlebih lagi berkaitan 
dengan pengelolaan keuangan. Arah pengembangan dalam peningkatan kapasitas dan penguatan kelembagaan adalah sebagai berikut:

a. Pelatihan untuk meingkatkan pengetahuan bisnis dan pengelolaan keuangan. literasi keuangan pada pemilik homestay yang mencakup edukasi tentang jasa keuangan dan pengelolaan keuangan. Literasi keuangan merupakan kombinasi antara kepedulian, pengetahuan, keahlian, sikap dan perilaku keuangan yang penting untuk pengambilan keputusan dan pencapaian kesejahteraan pribadi (Paranita et al., 2020)

b. Pelatihan untuk meningkatkan pelayanan usaha wisata (Homestay, guide/diver, speedboat, logistik, dan UMKM)

c. Pelatihan bahasa inggris

d. Pendidikan manajemen usaha wisata

e. Pendampingan untuk standarisasi bentuk homestay dan SOP yang harus diterapkan

f. Pembentukan dan penguatan kelembagaan usaha bersama pariwisata berbentuk koperasi

3. Konektivitas \& Digitalisasi

a. Akses pelaku usaha wisata terhadap konektivitas internet untuk menunjang kegiatan pariwisata.

b. Digitalisasi pengelolaan dan pelaporan sistem, layanan (pemesanan dan pembayaran), keuangan serta marketplace atau e-commerce.

c. Layanan mandiri yang mempermudah pelayanan pelaku usaha wisata berbasis mobile apps, yang menjadikan sebagai point of Central semua kebutuhan.

\section{KESIMPULAN}

Komunitas pemilik homestay Raja Ampat didefinisikan sebagai masyarakat asli Papua yang memiliki kepentingan bersama yaitu dalam mengelola homestay dan juga memiliki interaksi dan tujuan bersama untuk meningkatkan perekonomian dan mengelola wisata berkelanjutan di Raja Ampat. Dari total 38 pemilik homestay di Kampung Yenbuba dan Kampung Arborek diklasifikasikan dalam 3 skala usaha yaitu 13 persen skala usaha mikro, 74 persen skala usaha kecil, dan 13 persen skala usaha menengah. Adanya intervensi pihak luar berdampak pada kesadaran masyarakat untuk mengelola pariwisata berkelanjutan.

Dalam mengimplementasikan pembangunan berbasis masyarakat atau community based development pada sektor pariwisata harus melibatkan pihak luar seperti pemerintah, LSM, masyarakat sekitar dan juga pihak swasta. Peran dan intervensi tersebut berpengaruh pada dinamika sosial masyarakat asli yang sekarang beralih profesi menjadi pengelola wisata khususnya homestay.

Kendala-kendala yang dialami dalam pengelolaan usaha homestay yaitu kapasitas SDM yang masih lemah, terbatasnya akses pembiayaan, jaringan yang terbatas, belum adanya sinergi antar pelaku atau pengelola usaha pariwisata, serta konektivitas dan digitalisasi. Arah pengembangan yang ditawarkan dalam menjawab segala kendala yang ada adalah dengan diadakannya penguatan kapasitas, pembentukan koperasi atau bergabungnya pengelola homestay dengan koperasi yang sudah akif minimal satu tahun untuk memudahkan dalam mengakses pembiayaan dari LPDB, juga dirancangnya konektivitas dan digitalisasi untuk mengkonsolidasi seluruh pelaku usaha agar terintegritas dan dapat diakses melalui digital.

\section{DAFTAR PUSTAKA}

[BPS] Badan Pusat Statistik. (2020). Jumlah Kunjungan Wisatadi Kabupaten Raja Ampat 2013-2019. Raja Ampat: BPS

[Kemenparekraf] Kementerian Pariwisata dan Ekonomi Kreatif (2020). Laporan Kinerja Kementerian Pariwisata tahun 2019. https://kemenparekraf.go.id/laporan-kegiatan/Laporan-AkuntabilitasKinerja-Kemenparekraf Baparekraf

[Permen] Peraturan Menteri Pariwisata Republik Indonesia Nomor 29 tahun 2015 Tentang: Rencana Strategis Kementerian Pariwisata 2015-2019. 
https://www.kemenparekraf.go.id/post/peraturan-menteri-pariwisata-nomor-29-tahun-2015

[Pemkab] Pemerintah Kabupaten Raja Ampat (2018). Potensi Pariwisata Raja Ampat. https://lpse.rajaampatkab.go.id/eproc4/

[UU] Undang-Undang Republik Indonesia No 20 Tahun 2008 Tentang Usaha Mikro, Kecil, dan Menengah, (2017) https://peraturan.go.id/common/dokumen/ln/2013/pp17-2013bt.pdf

[UU] Undang-Undang Republik Indonesia No 26 Tahun 2002 Tentang Pembentukan Kabupaten Sarmi, Kabupaten Keerom,Kabupaten Sorong Selatan, Kabupaten Raja Ampat,Kabupaten Pegunungan Bintang, Kabupaten Yahukimo,Kabupaten Tolikara, Kabupaten Waropen,Kabupaten Kaimana, Kabupaten Boven Digoel, Kabupaten Mappi, Kabupaten Asmat, Kabupaten Teluk Bintuni, dan Kabupaten Teluk Wondama Di Provinsi Papua. https://peraturan.bpk.go.id/Home/Details/44483

Abdoellah, O. S., Sunardi, S., Widianingsih, I., \& Cahyandito, M. F. (2019). Pemetaan Sosial Dalam Perencanaan Program Pengembangan Ekowisata Berkelanjutan Citarum Hulu. Kumawula: $\begin{array}{lllll}\text { Jurnal Pengabdian } & \text { Kepada }\end{array}$ https://doi.org/10.24198/kumawula.v2i1.24461

Ade Yunita, I. (2019). Strategi Pengembangan Pariwisata Berdasarkan Preferensi Masyarakat Asli: Studi Kasus di Raja Ampat. In Jurnal Masyarakat dan Budaya. https://doi.org/10.14203/JMB.V21I3.731

Aini, N., Satria, A., \& Sri Wahyuni, E. (2019). Mechanisms of Access and Power in Strengthening the Performance of Marine Ecotourism Management Institutions. Sodality: Jurnal Sosiologi Pedesaan, 7(1), 65-77. https://doi.org/10.22500/sodality.v7i1.25308

Björk, P. (2000). Ecotourism from a conceptual perspective, an extended definition of a unique tourism form. International Journal of Tourism Research, 2(3). https://doi.org/10.1002/(sici)1522-1970(200005/06)2:3<189::aid-jtr195>3.3.co;2-k

Creswell, W. J., \& Creswell, J. D. (2018). Research Design: Qualitative, Quantitative adn Mixed Methods Approaches. In Journal of Chemical Information and Modeling (Vol. 53, Issue 9).

Febyarandika, S., Managemen, S. M., Pantai, S., Perikanan, F., Kelautan, D., Diponegoro, U., Abdul, M., Fakultas, C., Kelautan, T., Nadhatul, P., \& Cirebon, U. (2016). Tradisi Sasi Di Raja Ampat Papua. Tradisi Sasi Di Raja Ampat Papua, 11(1), 55-66. https://doi.org/10.14710/sabda.11.1.5566

Goeldner, C. R., \& Ritchie, J. R. B. (2005). Tourism: Principles, Practices and Philosophies. In John Wiley \& Sons, Inc., Hoboken, New Jersey.

Green, G. P. (2010). Community assets: Building the capacity for development. In Mobilizing Communities: Asset Building as a Community Development Strategy.

Hamsinah B. (2017). Perencanaan Dan Pengembangan Sumberdaya Terhadap Industri Pariwisata Di Kabupaten Raja Ampat, Papua Barat. Inovasi, 3(1). http://openjournal.unpam.ac.id/index.php/Inovasi/article/view/294

He, G., Chen, X., Liu, W., Bearer, S., Zhou, S., Cheng, L. Y., Zhang, H., Ouyang, Z., \& Liu, J. (2008). Distribution of economic benefits from ecotourism: A case study of Wolong Nature Reserve for Giant Pandas in China. Environmental Management, 42(6). https://doi.org/10.1007/s00267-0089214-3

Ife, J., \& Tesoriero, F. (2008). Community Development: Alternatif Pengembangan Masyarakat di Era Globalisasi. In Journal of Chemical Information and Modeling.

Irmawati, S., Damelia, D., \& Puspita, D. W. (2013). Model Inklusi Keuangan Pada Umkm Berbasis Pedesaan. Jejak: Jurnal Ekonomi Dan Kebijakan, 6(2), 103-213. https://doi.org/10.15294/jejak.v6i2.3885

Kenny, S., McGrath, B., \& Phillips, R. (2018). The Routledge handbook of community development: perspectives from around the globe. In Routledge handbooks.

Latuconsina, O. C., Syaukat, Y., \& Siregar, H. (2019). Strategi Pembiayaan Terhadap Pengembangan 
Pariwisata Berbasis Masyarakat Di Kota Ambon. Jurnal Manajemen Pembangunan Daerah, 5(2). https://doi.org/10.29244/jurnal_mpd.v5i2.24640

Nesparnas. (2017). Neraca Satelit Pariwisata Nasional (NESPARNAS).

Ningrum, L., Fadjar Boediman, S., \& Octarina, D. (2019). Homestay Desa Wisata di IndonesiaBagaimana Persepsi Masyarakat Kota? Jurnal Pariwisata, 6(1). http://ejournal.bsi.ac.id/ejurnal/index.php/jp80

Nugroho, T., \& Rusydiana, A. S. (2019). Strategi Pembiayaan Usaha Mikro dan Kecil Menengah pada Lembaga Pengelola Dana Bergulir di Indonesia The Strategy for Financing Micro and Small and Medium Enterprises in the Revolving Fund Management Institution in Indonesia. Jurnal Ekonomi Syariah Dan Bisnis, 3(1). http://jurnal.unma.ac.id/index.php/Mr/index

Oktadiyani, P., Harini Muntasib, E. K. ., \& Sunkar, A. (2016). Modal Sosial Masyarakat Di Kawasan Penyangga Taman Nasional Kutai (Tnk) Dalam Pengembangan Ekowisata. Jurnal Media Konservasi IPB, 18(1), 1-9. https://doi.org/https://doi.org/10.29244/medkon.18.1.\%25p

Paranita, E. S., Levyda, L., \& Giyatmi, G. (2020). Peningkatan Literasi Keuangan Pemilik Homestay Di Pulau Harapan Kepulauan Seribu. Wasana Nyata, 3(2), 157-167. https://doi.org/10.36587/wasananyata.v3i2.528

Phillips, R., \& Pittman, R. H. (2009). framework for community and economic development in An Introduction of Community Development. Routledge, (Pp 3-19). www.prattcenter.net/cdcoralhistory.php

Pongantung, N. V. (2018). Perubahan Sosial Budaya Dan Ekonomi Masyarakat Kampung Arborek Kabupaten Raja Ampat Setelah Menjadi Kawasan Wisata. Agri-Sosioekonomi, 14(1), 109. https://doi.org/10.35791/agrsosek.14.1.2018.19008

Reed, M. S., Graves, A., Dandy, N., Posthumus, H., Hubacek, K., Morris, J., Prell, C., Quinn, C. H., \& Stringer, L. C. (2009). Who's in and why? A typology of stakeholder analysis methods for natural resource management. Journal of Environmental Management, 90(5), 1933-1949. https://doi.org/10.1016/j.jenvman.2009.01.001

Seventythree Ltd. (2013). Training entrepreneurs in Raja Ampat, West Papua. https://www.73ltd.com/training-entrepreneurs-in-raja-ampat-west-papua/

Steelyana, E. (2013). Perempuan dan Perbankan: Sebuah Tinjauan Tentang Peran Inklusi Keuangan terhadap Pengusaha UMKM Perempuan di Indonesia. The Winners, 14(2), 95. https://doi.org/10.21512/tw.v14i2.649

Sumartono. (2020). Dinamika Perubahan Sosial Dalam Teori Konflik. In Jurnal Ilmu Komunikasi dan Bisnis (Vol. 5, Issue 1). https://doi.org/10.36914/JIKB.V5I1.259

Tanati, E., Wahyudi, W., \& Sinery, A. S. (2020). Tingkat Partisipasi Masyarakat Lokal dalam Pengelolaan Ekowisata di Kampung Saporkren Distrik Waigeo Selatan Kabupaten Raja Ampat. Jurnal Sumberdaya Akuatik Indopasifik, 4(2), 193. https://doi.org/10.46252/jsai-fpikunipa.2020.vol.4.no.2.118

Tejokusumo, B. (2014). Dinamika Masyarakat Sebagai Sumber Belajar Ilmu Pengetahuan Sosial. Geoedukasi, 3.

World Travel and Tourism Council. (2020). Travel and Tourism: World Economic Impact 2019, World Travel and Tourism Council. Current Issues in Tourism, 75(3). 